\title{
Polygenic Nature of Olivines from the Ultramafic Lamprophyres of the Terina Complex (Chadobets Upland, Siberian Platform) Based on Trace Element Composition, Crystalline, and Melt Inclusion Data
}

\author{
Anastasiya Starikova 1,2,*D, Ilya Prokopyev ${ }^{1,2} \mathbb{D}$, Anna Doroshkevich ${ }^{1,3, *}$, Alexey Ragozin ${ }^{1,2} \mathbb{D}$ and \\ Vasily Chervyakovsky ${ }^{4}$ \\ 1 Sobolev Institute of Geology and Mineralogy, Siberian Branch of the Russian Academy of Sciences, \\ 630090 Novosibirsk, Russia; prokop@igm.nsc.ru (I.P.); ragoz@igm.nsc.ru (A.R.) \\ 2 Department of Geology and Geophysics, Novosibirsk State University, 630090 Novosibirsk, Russia \\ 3 Geological Institute, Siberian Branch of the Russian Academy of Sciences, 670047 Ulan-Ude, Russia \\ 4 Zavaritsky Institute of Geology and Geochemistry of the Ural Branch of the Russian Academy of Sciences, \\ 620016 Ekaterinburg, Russia; chervyakovskiy@igg.uran.ru \\ * Correspondence: a_sklr@mail.ru or starikova@igm.nsc.ru (A.S.); doroshkevich@igm.nsc.ru (A.D.); \\ Tel.: +7-913-207-8362 (A.S.)
}

Citation: Starikova, A.; Prokopyev, I.; Doroshkevich, A.; Ragozin, A.; Chervyakovsky, V. Polygenic Nature of Olivines from the Ultramafic Lamprophyres of the Terina Complex (Chadobets Upland, Siberian Platform) Based on Trace Element Composition, Crystalline, and Melt Inclusion Data. Minerals 2021, 11, 408 https://doi.org/10.3390/min11040 408

Academic Editor: Federica Zaccarini

Received: 26 February 2021

Accepted: 10 April 2021

Published: 13 April 2021

Publisher's Note: MDPI stays neutral with regard to jurisdictional claims in published maps and institutional affiliations.

Copyright: (c) 2021 by the authors. Licensee MDPI, Basel, Switzerland. This article is an open access article distributed under the terms and conditions of the Creative Commons Attribution (CC BY) license (https:/ / creativecommons.org/licenses/by/ $4.0 /)$.

\begin{abstract}
Olivine from the deep mantle-derived rocks, such as ultramafic lamprophyres, carries important information about the composition of the mantle source, the processes of mantle metasomatism, the origin of specific silicate-carbonate melts, as well as the composition and mechanisms of crystallization of these rocks. Textures and compositions of olivine from the carbonate-rich ultramafic lamprophyres (aillikites) of the Terina complex, along with their mineral and melt inclusions, exposed that olivines have different sources. Two populations of olivines were considered: macrocrysts $(>1 \mathrm{~mm})$ and groundmass olivines $(<1 \mathrm{~mm})$. Groundmass olivines are phenocrysts and characterized by weak variations in $\mathrm{Mg \#} \mathrm{(84-86.5),} \mathrm{a} \mathrm{sharp} \mathrm{increase} \mathrm{in} \mathrm{Ca}$ and $\mathrm{Ti}$ contents, and a decrease in $\mathrm{Ni}$ and $\mathrm{Cr}$ from core to rim. They have higher concentrations of $\mathrm{Li}, \mathrm{Cu}, \mathrm{Ti}$, and $\mathrm{Na}$ compared to macrocrysts. Among the macrocrysts, the following populations are observed: (1) high-Mg olivines (Mg\# 89-91) with high $\mathrm{Ni}$ and low Ti contents, which are interpreted as xenocrysts from the slightly depleted lherzolite mantle; (2) high-Ca olivines (Mg\# 84-88, CaO 0.13-0.21 wt \%), which have patterns similar to groundmass olivines and are interpreted as cumulates of early portions of aillikite melt; (3) macrocrysts with wide variations in $\mathrm{Mg \#} \mathrm{(73-88),} \mathrm{low} \mathrm{CaO}$ contents (0.04-0.11 wt \%), and positive slope in Ca vs. $\mathrm{Al}$ and negative slope in $\mathrm{Ca}$ vs. $\mathrm{Mn}$, which are interpreted as disintegrated megacrysts from the Cr-poor megacryst suite. The megacryst suite could have been formed in the pre-trap period during the melting of the metasomatized subcontinental lithospheric mantle (SCLM). The aillikite melt evolution is traced by secondary melt inclusions in olivine macrocrysts: early phlogopite-diopside-calcite-apatite association, containing Ti-magnetite and ilmenite, is followed by an association with magnetite and sulfides (pyrrhotite and pentlandite); finally, at a late stage, inclusions with a predominance of Ca-Na-carbonates and sulfates and enriched in U, Th, Y, REEs, Sr, and Ba were captured.
\end{abstract}

Keywords: olivine; melt inclusion; ultramafic lamprophyre; aillikite; Siberian craton

\section{Introduction}

Aillikites are carbonate-rich ultramafic lamprophyres (UMLs) [1]. As group I kimberlites, they are igneous rocks with a deep mantle source, which do not bear significant signs of assimilation of crustal material captured during the rise of the melt [1-3]. Like kimberlites, they are significantly depleted in $\mathrm{SiO}_{2}\left(18-35 \mathrm{wt} \% \mathrm{SiO}_{2}\right)$ and are characterized by a high total content of magmatic carbonates [4-6]. A distinctive feature of aillikites 
is their higher Fe content (compared to kimberlites) [7]. Their genetic relationship with kimberlites is a matter of debate [7-10]. The frequent association of aillikites with continental rifting suggests that a thinner lithosphere is required for the formation of aillikite melts than for the kimberlite formation. However, Tape et al. [8,9] discuss the possibility of aillikite melt formation at the boundary with a thick lithosphere as a result of melting of a mantle source that contains phlogopite- and carbonate-rich veins. Thus, aillikites carry important information about the processes occurring at the boundary of the asthenosphere and the lithospheric mantle and the composition of mantle rocks that were a source of material for parental melts. However, the exposure of the rocks to later hydrothermal processes makes difficult use of conventional geochemical techniques to determine the composition of parental melts and the contribution of various mantle sources for the formation of these rocks. As an alternative, many researchers use the macro- and microelemental compositions of the primary magmatic minerals [11-13].

As one of the main mineral components of kimberlites and UMLs, olivine has attracted close attention from geologists and geochemists [14-26]. As a liquidus mineral, olivine can be a useful source of information about the initial composition and further evolution of melts. However, it has been proven that most of the olivines in kimberlites ( $>50 \mathrm{vol} \%)$ are xenogenic [15-20]. It has been shown that large macrocrysts are xenogenic and that the central parts of small idiomorphic olivines (groundmass olivines) can represent disintegrated and partially dissolved parts of xenocrysts. These served as seeds for the growth of olivine from the kimberlite melt proper. Many works have considered the specifics of the olivine compositions, which make it possible to separate phenocrysts from xenocrysts in kimberlites, but the most attention has been devoted to those olivines that crystallized directly from the kimberlite melt [15-18]. Recently, interest in xenogenic olivine as a source of information about the lithospheric mantle has noticeably increased [20-22], with very few publications devoted to the detailed study of olivines from aillikites $[23,24,26]$. Our data on the trace element composition (WDS, ICP-LA) of olivine from the aillikites of the Terina complex (Siberian platform) could make a significant contribution to the creation of a database on UMLs, as well as support the further development of geochemical criteria to determine the composition of the mantle source and the evolutionary features of UML melts. In this work, olivines of different genetic types are established in aillikites and an interpretation of their origin is given based on their geochemical data, morphology, and inclusions. The xenogenic nature of some macrocrysts is proven, and possible sources are suggested.

\section{Geological Setting}

The Terina complex of ultramafic lamprophyres and carbonatites is located in the northern part of the Chadobets alkaline complex, which is confined to the Chadobets upland of the Siberian craton (Figure 1). The Chadobets upland is a part of the AngaraKotuy large-scale rift system situated at the intersection of two Neoproterozoic graben basins [27-29]. Emplacement of the Chadobets alkaline rocks includes several stages of the intrusion of aillikites, mela-aillikites, carbonatites, and damtjernites. The crystallization of the rocks has been related to the Permian-Triassic Siberian plume activity forming the Siberian large igneous province (LIP), and the Chadobets UML-carbonatite complex was intruded in the southern part of the Siberian plume activity (Figure 1a) [30-34]. The dates for the Chadobets rocks are $256.7 \pm 1.1 \mathrm{Ma}$ and $252 \pm 12 \mathrm{Ma}$ (zircon from damtjernite, and perovskite from aillikite, respectively, U-Pb, Chuktukon complex) [31,33], 243.4 \pm 3.1 and $241 \pm 1 \mathrm{Ma}$ (Ar-Ar, phlogopite, and Rb-Sr, respectively, aillikites from Terina complex) [32], and $231 \pm 2.7 \mathrm{Ma}$ (rippite, Ar-Ar, Chuktukon carbonatites) [31]. So, the emplacement of the Chadobets complex rocks could be assumed as 257-241 Ma.

UMLs of the early phases of the Chadobets alkaline complex include dykes and sills ranging from 150-250 $\mathrm{m}$ to $1-3 \mathrm{~km}$ in length [27-29,34-36] (Figure 1b). The alkaline intrusions have a banded structure and are predominantly located in the Terina complex. The next phase of the Chadobets complex is the formation of carbonatite stocks up to $3 \mathrm{~km}$ 
in diameter, as well as dykes and sills up to $200-400 \mathrm{~m}$ long. They are predominantly located within the Chuktukon complex (Figure 1b). The carbonatite dykes have a crosscutting contact with the early phase UMLs. Damtjernites intruded into the previous magmatic phases and hosting metasedimentary rocks and contain xenoliths and fragments of the latter. The damtjernites form pipes and diatremes of up to 20-30 $\mathrm{m}$ in diameter and are usually located in the central parts of the Chuktukon and Terina complexes (Figure 1b).

The Chadobets complex intruded the Neoproterozoic and Cambrian metasedimentary rocks: schists, sandstones, dolostones, and siltstones (Figure 1b). The Chadobets complex is surrounded by the Permian-Carboniferous and Lower Triassic sedimentary rocks: sandstones, argillites, siltstones, conglomerates, dolostones, coal, pebbles, and tuffs, as well as an area of surrounding Permo-Triassic traps (Figure 1b). The silicate rock bodies of the Chadobets complex were subjected to the intense processes of hydrothermal-metasomatic alterations and contained K-feldspar-aegirine and apatite-phlogopite fenite zones [34-36].
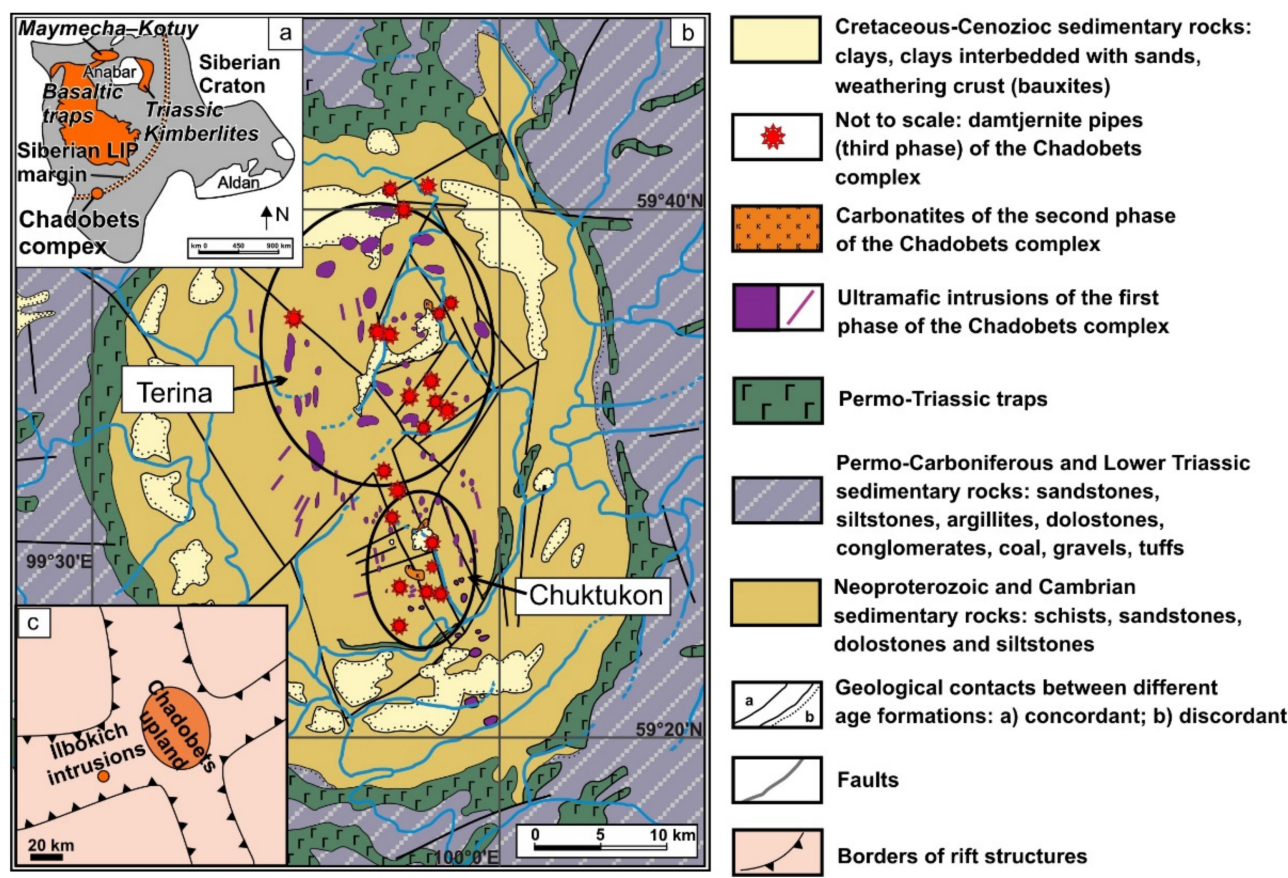

Figure 1. (a) Location of the Chadobets alkaline complex within the Siberian large igneous province (LIP) on the Siberian craton [37]. (b) Geological map of the Chadobets ultramafic lamprophyre (UML)carbonatite complex $[27,34]$. (c) Location of the Devonian Ilbokich complex within the Angara-Kotuy rift system [27,31].

The alkaline silicate rocks of the Terina complex are represented by aillikites, melaaillikites, and damtjernites [23,38], and they can be classified as intrusive coherent intrusive lamprophyres, according to [39], with a varying content of phenocrysts (20-60 modal\%). The phenocrysts are mainly olivine (20-40 modal \%), less commonly phlogopite, clinopyroxene, or magnetite. The mineral composition of the rocks is characterized by fine-grained aggregates of clinopyroxene, biotite, dolomite, calcite, apatite, and in some cases, potassium feldspar, as well as ore minerals, which are present at $15-17$ modal\% (Cr-spinels, Ti-magnetite, magnetite, perovskite, rarely ilmenite and sulfides). The petrography and mineralogy of the Terina UMLs are described in more detail in another study [38].

The Devonian Ilbokich UML complex is located approximately $70 \mathrm{~km}$ to the southwest of the Chadobets upland (Figure 1c). The age of crystallization of the Ilbokich UMLs is $399 \pm 4 \mathrm{Ma}$ (perovskite, U-Pb) [32]. The aillikite and damtjernite dykes, which form the Ilbokich UML complex, are up to 5-10 m thick [23]. The formation processes of the alkaline rocks of the Ilbokich UML complex play an important role in the origin of aillikite 
melts beneath the Siberian craton in Devonian and the formation of the Chadobets UMLcarbonatite complex during the Siberian plume activity [23].

\section{Analytical Methods}

The analytical work was performed using the facilities of the Analytical Center for Multi-Elemental and Isotope Research at the V.S. Sobolev Institute of Geology and Mineralogy (IGM) and the Novosibirsk State University (NSU) in Novosibirsk, Russia. Samples of Terina complex aillikite were collected from the exploratory drill cores and the Terina River banks outcrop rocks. Out of more than 50 studied samples, preserved olivines were found only in 13 probes. Thin-sections were made for each sample, which were taken for petrographic and mineralogical studies. Most of all samples with olivines were hand polished in dry conditions with diamond pastes, using benzene or alcohol to preserve water-soluble phases in the inclusions.

Olivine mineral chemistry was determined on an electron probe microanalyzer (Jeol JXA-8100) at the IGM. The operation conditions were: $250 \mathrm{nA}$ beam current and $20 \mathrm{kV}$ accelerating voltage; the count time on peak per element was $15 \mathrm{~s}$ for $\mathrm{Si}, \mathrm{Mg}$, Fe; $60 \mathrm{~s}$ for $\mathrm{Zn}$ and $\mathrm{Ca} ; 90 \mathrm{~s}$ for $\mathrm{Ni}, \mathrm{Co}, \mathrm{Al}$, and $\mathrm{Cr}$; and $120 \mathrm{~s}$ for $\mathrm{P}$ and $\mathrm{Ti}$. The data were calibrated against the standards of olivine $\mathrm{Ch} 1(\mathrm{Si}, \mathrm{Mg}, \mathrm{Fe})$, pyrope $(\mathrm{Al}), \mathrm{Mn}$-garnet $(\mathrm{Mn})$, blue diopside $(\mathrm{Ca}), \mathrm{Co}_{3} \mathrm{O}_{4}(\mathrm{Co}), \mathrm{NiFe}_{2} \mathrm{O}_{4}(\mathrm{Ni}), \mathrm{ZnFe}_{2} \mathrm{O}_{4}(\mathrm{Zn}), \mathrm{TiO}_{2}(\mathrm{Ti}), \mathrm{Cr}_{2} \mathrm{O}_{3}(\mathrm{Cr})$, and fluorapatite $(\mathrm{P})$. The $\mathrm{ZAF}$ procedure was applied for matrix correction. The relative standard deviation (RSD) was less than 0.3 rel.\% for the major elements, less than 3 rel.\% for $\mathrm{Ni}, \mathrm{Mn}$, and Ca; 8-15 rel.\% for $\mathrm{Al}, \mathrm{Co}$, and Ti; and 15-30 rel.\% for $\mathrm{Cr}$ and $\mathrm{P}$. To monitor stability and instrumental drift, San Carlos olivine (USNM 111312/444) was used as an internal standard. Detection limits ( $3 \sigma)$ for trace elements were (wt \%): $0.001(\mathrm{CaO}), 0.002\left(\mathrm{Al}_{2} \mathrm{O}_{3}, \mathrm{P}_{2} \mathrm{O}_{5}, \mathrm{MnO}\right)$, $0.003\left(\mathrm{NiO}, \mathrm{CoO}, \mathrm{TiO}_{2}\right)$, and $0.005\left(\mathrm{Cr}_{2} \mathrm{O}_{3}, \mathrm{ZnO}\right)$.

The trace element composition of olivines was analyzed by laser-ablation mass spectrometry with inductively coupled plasma (LA-ICP-MS) on a Thermo Scientific XSERIES2 ICP-MS quadrupole mass spectrometer at NSU. The plasma source was equipped with a $1.6 \mathrm{~kW}$ generator with a $27.12 \mathrm{MHz}$ working frequency. The mass spectrometer was coupled with a New Wave Research, Nd:YAG $213 \mathrm{~nm}$ laser-ablation system (Al-Y garnet, $\sim 3 \mathrm{wt} \% \mathrm{Nd}_{2} \mathrm{O}_{3}$ ). The data were calibrated using a NIST 612 glass as an external standard and Hf determined by EMPA as an internal standard. The mass spectrometer parameters were optimized against a solution of $10 \mathrm{mg} / \mathrm{L} \mathrm{Mg}$, In, Ce, Ba, and $\mathrm{U}$ in $0.5 \% \mathrm{HNO}_{3}$. The concentrations of elements in dry aerosol obtained using the laser ablation system were determined by peak jumping. The resolution corresponding to the peak width was set at $0.7 \mathrm{apfm}$, and the peak intensity for each element was measured in the middle of the mass range for each element. The count time was 2-4 min per point, including $1 \mathrm{~min}$ for a background measurement. The beam size was $50 \mu \mathrm{m}$. The element contents were considered significant when their intensity was at least three times the background value. Detection limits are 0.001 to $1 \mathrm{ppm}$ for all elements except $\mathrm{Si}$ (12 ppm), Ti (4 ppm), and $\mathrm{Cr}$ (3 ppm). The RSD (rel\%) are: 5-10 (Na, Al, Cr, Co, Mn, Ni, Ca), 10-20 (P, Sc, Si, V, Zn), and 20-30 (Li).

The microelement composition of some olivine grains was also measured on a NexION $300 S$ ICP-MS (PerkinElmer) equipped with an NWR 213 (ESI) attachment for laser ablation (LA), located in an ISO 7 room at the Common Use Center of the Ural Branch of RAS "Geoanalyst" (Yekaterinburg, Russia). The results were calculated using GLITTER V4.4 program using an internal standard, $\mathrm{FeO}$, and a standard glass NIST SRM 610 was used as a primary external standard (standard glass NIST SRM 612 was used as a secondary standard), measured by the "plugging" method after 10-12 measurements. The crater diameter is 25 or 50 microns.

Solid phases in inclusions were identified using a Tescan MIRA 3MLU scanning electron microscope equipped with an Oxford Instruments INCA Energy 450+/Aztec Energy XMax 80 microanalysis system and an Oxford Instruments Inca Wave 500 nanoanalysis system (IGM). The instruments were operated at $20 \mathrm{keV}$ beam energy and $1.5 \mathrm{nA}$ beam 
current, with a $20 \mathrm{~s}$ live spectrum acquisition time. The results were checked against the standards $\mathrm{SiO}_{2}(\mathrm{Si}, \mathrm{O}), \mathrm{Al}_{2} \mathrm{O}_{3}(\mathrm{Al})$, diopside $(\mathrm{Mg}, \mathrm{Ca})$, albite $(\mathrm{Na})$, orthoclase $(\mathrm{K}), \mathrm{Ca}_{2} \mathrm{P}_{2} \mathrm{O}_{7}$ $(\mathrm{P}), \mathrm{BaF}_{2}(\mathrm{Ba}, \mathrm{F}), \mathrm{Cr}_{2} \mathrm{O}_{3}(\mathrm{Cr})$, pyrite $(\mathrm{S}), \mathrm{CsRe}_{2} \mathrm{Cl}_{6}(\mathrm{Cs}, \mathrm{Cl}), \mathrm{Ti}, \mathrm{Fe}, \mathrm{Mn}$, and $\mathrm{Zn}$. The matrix correction was by the XPP method using the built-in software. Metallic Co was used for beam current normalization and beam energy calibration.

Raman spectra were acquired on a Horiba LabRAM HR $800 \mathrm{~mm}$ spectrometer coupled with a CCD detector and an Olympus BX40 confocal microscope $(\times 100)($ IGM), using a $514.5 \mathrm{~nm}$ laser excitation at $50 \mathrm{~mW}$, to a spectral resolution of $2-2.5 \mathrm{~cm}^{-1}$. The monochromator was calibrated against the silica band $\left(520.7 \mathrm{~cm}^{-1}\right)$. The RRUFF (http:/ / rruff.info, accessed on 12 April 2021) database was used to identify the solid phases of olivine inclusions.

The concentrations of chemical elements in individual melt inclusions were determined using LA-ICP-MS methods on the Thermo Scientific XSERIES2 ICP-MS quadrupole mass spectrometer at NSU (described above). To correct for the matrix effect and sensitivity drift of the instrument, an internal standard was used. According to the melt inclusion investigation, olivine inclusions contain the daughter-phase of calcite, which occupies about 45-50 vol \%. The CaO content in the calcite was determined by SEM/EPMA analyses of the opened melt inclusions and was 54.02-54.16 wt \%. Therefore, the concentration of Ca was calculated and used as an internal standard in the calculations. To obtain the analytical signal related to the composition of the inclusion, the average value of the analytical signal of each element recorded during the ablation of the host mineral was subtracted from the average value of the analytical signal over the ablation interval of the melt inclusion. To calculate the element concentrations in the melt inclusions, an algorithm, based on Longerich's formula for calculating LA-ICP-MS analysis results, was used for NIST 612 [40]. The element concentrations (wt \% and ppm) within an inclusion are determined by normalizing the absolute results to the ratio of the Ca concentration in the sample at the time of the inclusion opening to the Ca concentration in the inclusion obtained by an exterior method. A similar calculation algorithm has been used in many publications dealing with the LA-ICP-MS analysis of melt and fluid inclusions [41-44]. In order to estimate the detection limits depending on the size of the laser beam, analyses were carried out with apertures equal to 15 and $50 \mu \mathrm{m}$. For a beam size of $50 \mu \mathrm{m}$, detection limits are 0.001 to 1 ppm for all elements except Si (12 ppm), Ti (4 ppm), and Cr (3 ppm). With a decrease in aperture from 50 to $15 \mu \mathrm{m}$, detection limits are lower by approximately an order of magnitude.

\section{Results}

The studied ultramafic lamprophyres of the first phase of intrusion of the Chadobets complex are aillikites and mela-aillikites (Figure 2). The rocks have a porphyry structure; the proportion of phenocrysts varies from 20 to 60 modal \%. Macrocrysts are represented by olivine grains (up to 20 modal \%), which are completely or partially replaced by serpentine and calcite. Hypidiomorphic phlogopite flakes (up to 15-20 modal \%) have a zonal structure with a magnesian core (Mg\# 0.78-0.73) overgrown by an Fe-enriched rim (Mg\# 0.47-0.12). Mela-aillikites differ from the aillikites by the presence of hypidiomorphic or idiomorphic elongated clinopyroxene crystals up to 10 modal \% (diopside core with an aegirine rim) (Figure 2d). The groundmass of ultramafic lamprophyres contains calcite, dolomite, and phlogopite, as well as disseminated micrograins of $\mathrm{Cr}$-spinel, ilmenite, titanomagnetite, apatite, and rare sulfides (pyrrhotite, pentlandite, etc.).

\subsection{Olivine Morphology}

Olivine is the main mineral of the Terina aillikites, and its grains are often completely or partially replaced by a mixture of serpentine and carbonates. Depending on the size and morphology of the olivine crystals, two populations can clearly be distinguished: (1) large (1-10 mm) subrounded or subhedral grains and (2) small (<1 mm) euhedral or subrounded grains. We refer to the first population of olivine as "macrocrysts" and the second as "groundmass olivines", according to [20,23]. This classification avoids 
the genetic linkages that arise from the division of the populations into xenocrysts and phenocrysts. This division is based only on morphological features and has been inconsistent for UMLs and related kimberlites because central parts of groundmass olivines can also be xenogenic $[6,17,19]$. The first olivine population (i.e., macrocrysts) also includes the multigranular aggregates of hypidiomorphic olivine grains (Figure 2c) called nodules $[17,18,45]$. For different UMLs of the Terina complex, the ratio of these populations is different, but, as a rule, macrocrysts prevail as 50 to 90 modal \% of the total amount of olivine grains. Most of the rims of both macrocrysts and groundmass olivines are replaced by the secondary minerals, which significantly reduces the representative analyses.
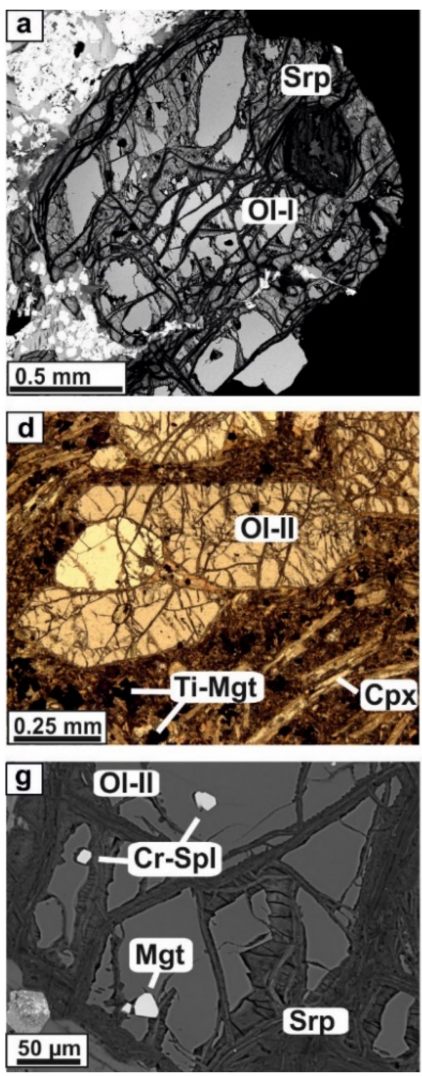
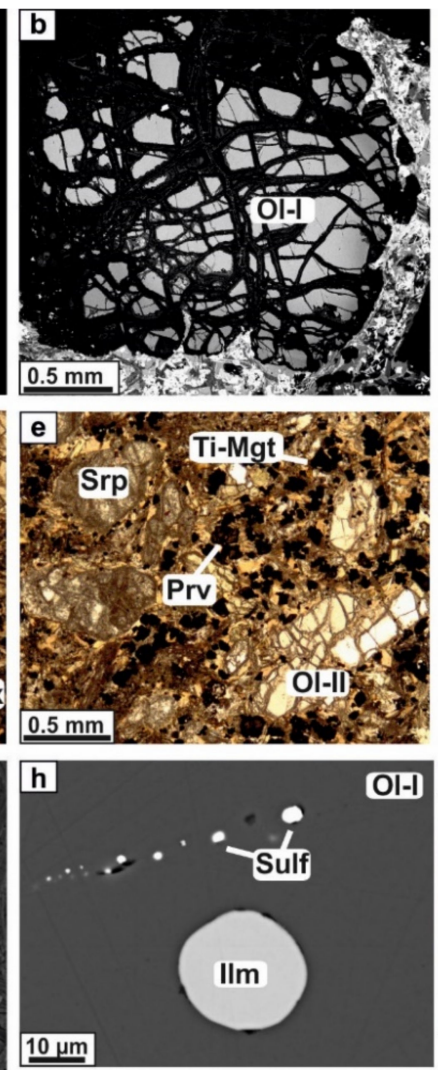
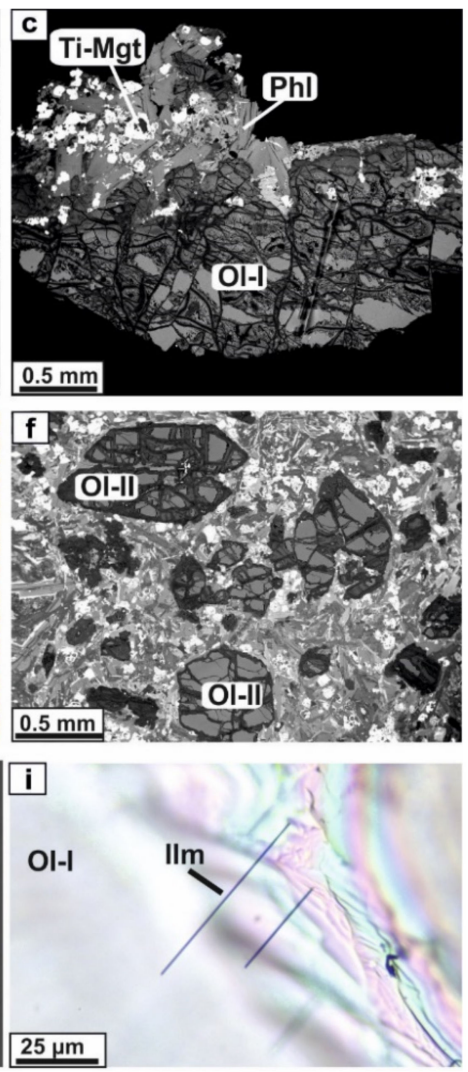

Figure 2. Back-scattered electron (BSE) images $(\mathbf{a}-\mathbf{c}, \mathbf{f}-\mathbf{h})$ and microphotographs in transmitted light $(\mathbf{d}, \mathbf{e}, \mathbf{i})$ of olivines from the UMLs of the Terina complex. $(\mathbf{a}-\mathbf{c})$ Olivine macrocrysts partly replaced by serpentine: $(\mathbf{a}, \mathbf{b})$ macrocrysts (G3) with reverse zoning, where Mg-rich rims surround more Fe-rich cores; (c) a multigranular nodule of olivine with a completely replaced rim. (d-f) Euhedral groundmass olivine: (d) extremely rare occurrence of unaltered olivine grain in the groundmass; (e) practically fresh grains of groundmass olivine coexisting with grains completely replaced by a mixture of serpentine and calcite in a groundmass that consists of phlogopite, apatite, clinopyroxene, carbonates, Ti-rich magnetite, and perovskite; (f) BSE image of a typical aillikite section. $(\mathbf{g}-\mathbf{i})$ Crystalline inclusions in groundmass olivine $(\mathbf{g})$ and olivine macrocrysts $(\mathbf{h}, \mathbf{i})$ : (g) fine idiomorphic spinel grains in groundmass olivine, Cr-spinels in the central part and magnetite in the rim; (h) a rounded ilmenite grain entrained during the growth of the olivine macrocryst (G2), and a chain of sulfides inclusions that are secondary to the olivine; (i) regular intergrowths of thin ilmenite blades with a high-Fe macrocryst (G4). Cpx-clinopyroxene, Cr-Spl-Cr-rich spinel, Ilm-ilmenite, Ol-I—macrocryst, Ol-II—groundmass olivine, Phl—phlogopite, Sulf—sulfides, Prv—perovskite, Srp-serpentine, Ti-Mgt-Ti-rich magnetite. 


\subsection{Olivine Chemical Composition}

\subsubsection{Macrocrysts}

The central parts and rims can be distinguished in all weakly altered olivine macrocrysts. The thickness of the rims is $0.5-0.25 \mathrm{~mm}$, and they are darker in backscattered electron (BSE) images than cores (Figure 2a,b). The macro- and microcomponents vary little within the central zone of a single grain but can dramatically differ even for neighboring macrocrysts. Macrocrystic olivine can be subdivided into four groups according to the $\mathrm{Mg} \#[=100 \times \mathrm{Mg} /(\mathrm{Fe}+\mathrm{Mg})]$ of macrocrysts (Figure 3a).
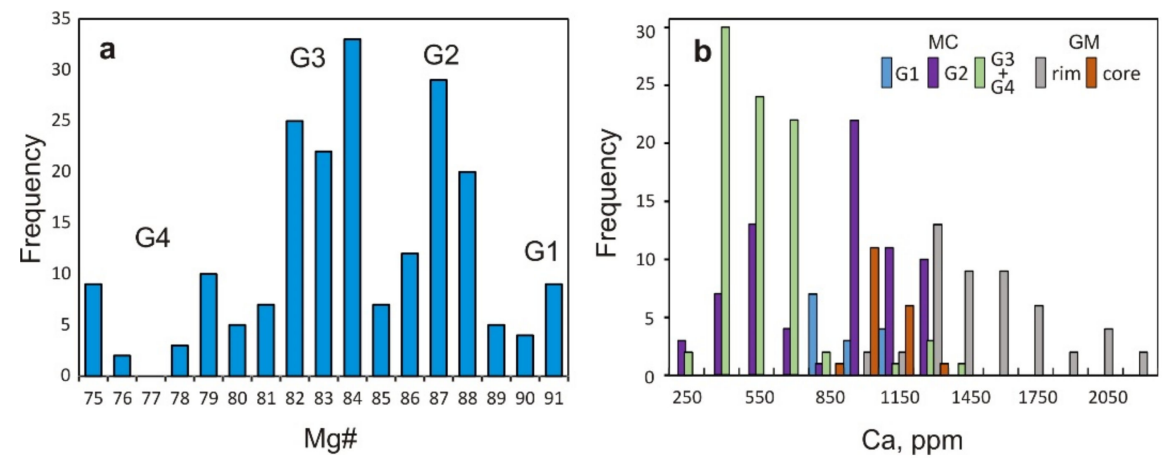

Figure 3. Histogram of $\mathrm{Mg \#} \mathrm{(a)} \mathrm{and} \mathrm{Ca} \mathrm{(b)} \mathrm{contents} \mathrm{in} \mathrm{olivines.} \mathrm{MC—compositions} \mathrm{of} \mathrm{macrocrysts:}$ (G1)—high-Mg core, (G2)—core having Mg\# similar to that of groundmass olivines, (G3)—core with low Mg\#, (G4) — core with anomalously low Mg\#; GM-groundmass olivines: rim-composition of rims, core-composition of the central part. $\mathrm{Mg} \#=100 \times \mathrm{Mg} /(\mathrm{Fe}+\mathrm{Mg})$.

The first group of olivine macrocrysts (G1) has a high Mg\# and is rare. These olivines are characterized by a maximum concentration of $\mathrm{Mg} \#$ of $89-90.5 \%$, high concentrations of $\mathrm{Ni}$ (2640-2900 ppm), Cr (250-300 ppm), and low Mn (950-1180 ppm) (Figure 4). The Ca content is 800-1060 ppm (Figures 3b and 4a). For these olivines, lower concentrations of Ti ( $<100 \mathrm{ppm})$, $\mathrm{P}$ (35-50 ppm), Co (130-155 ppm), and Zn (57-86 ppm), and an increased concentration of $\mathrm{Al}(100-200 \mathrm{ppm}$ ) are typical (Figure 5). The complete composition of trace elements for all analyzed olivines is presented in Tables S1 and S2 (Supplementary Materials).

Macrocrysts of the olivines of the second group (G2) have a Mg\# of 84-88, similar to or higher than that for the groundmass olivines (Figures $3 a$ and $4 a, b)$, and have a wide range of trace element values: $\mathrm{Ca}, 150-1200$ ppm; Ni, 2040-3190 ppm; Mn, 950-1760 ppm; $\mathrm{Cr}$, 0 to $365 \mathrm{ppm}$; $\mathrm{Al}, 20-305 \mathrm{ppm}$; , up to $100 \mathrm{ppm}$; Ti, up to $400 \mathrm{ppm}$; $\mathrm{Co}, 140-210 \mathrm{ppm}$; and Zn, 55-145 ppm (Figure 4a,b and Figure 5, Tables S1 and S2).

Macrocrysts of the third group (G3) have increased iron content (Mg\# 80-84) (Figure 3a). This group is characterized by low contents of $\mathrm{Ni}$, 73-2000 ppm; Cr, up to $140 \mathrm{ppm}$; and Ca, 250-790 ppm. Mn is also high: 1160-3110 ppm (Figure 4a, Tables S1 and S2). At the same time, with increased iron content, a decrease in the concentrations of $\mathrm{Ca}$ and $\mathrm{Ni}$ and an increase in $\mathrm{Mn}$ are observed. The compositions of the nodular olivines coincide with those of the third group of macrocrysts (Figure 4a) and, most likely, are disintegrated macrocrysts. Therefore, they will be considered with them.

The macrocrystal core of the fourth group of olivines (G4) has an abnormally low $\mathrm{Mg}$ content (Mg\# 74-80) (Figure 3a), together with low Ca (250-520 ppm) and Ni (34-1385 ppm), and maximum Mn concentrations of 1450-2150 ppm (Figure 4a, Table S1). (G4) olivines are characterized by a minimum concentration of $\mathrm{Al}$ (up to $55 \mathrm{ppm}$ ) and a maximum of $\mathrm{Zn}$ (180-270 ppm) (Figure 5, Table S2). 


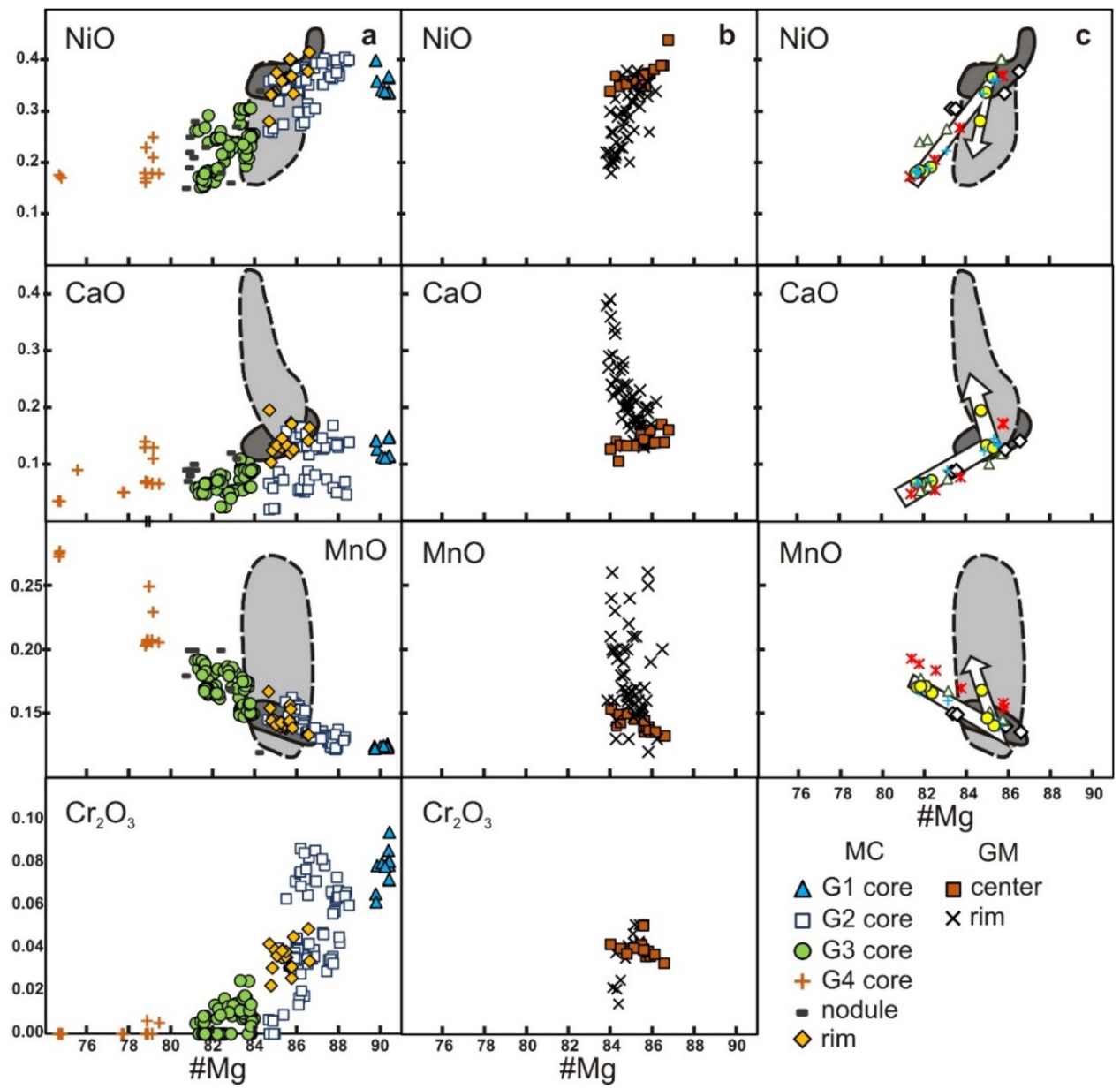

Figure 4. Compositional variations of olivines, $\mathrm{Mg} \#$ vs. $\mathrm{NiO}, \mathrm{CaO}, \mathrm{MnO}$, and $\mathrm{Cr}_{2} \mathrm{O}_{3}$ (wt\%). (a) Compositions of different groups of macrocrysts (MC); (b) groundmass olivines (GM); (c) compositions of zonal macrocrysts (G3), where the same symbols indicate the profile of one grain. The arrow shows the direction from core to rim, dark gray field - compositions of the central parts of groundmass olivines, light gray field—compositions of the rims of groundmass olivines, nodule—compositions of olivines from nodules.

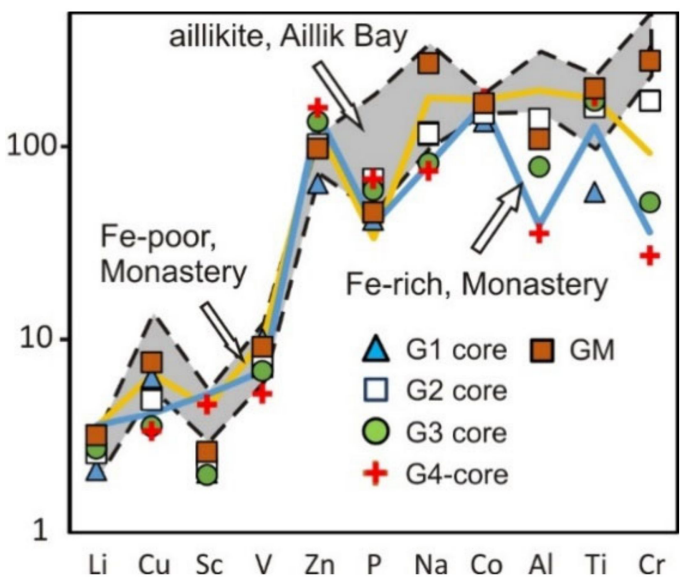

Figure 5. Average trace element composition (ppm) of groundmass olivines and olivine macrocrysts. Legend as in Figure 4. The composition of the central parts of olivine phenocrysts from the aillikites of Aillik Bay (gray field) [24], as well as the average contents of olivines from the Cr-poor megacryst suite from the Monastery kimberlite [46], were provided for comparison. 
Surviving rims were found only in macrocrysts of the third group. For all of the rims,

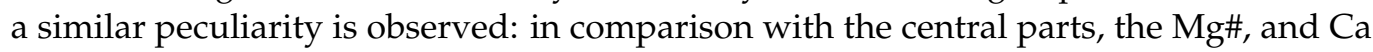
and Ni concentrations sharply increase, while the Mn content decreases (Figure 4c). The compositions fall into the region of the central zones of the groundmass olivines. In single grains of macrocrysts, an outer zone of rim characterized by a sharp increase in the Ca concentration, a decrease in the $\mathrm{Ni}$ concentration, and a slight decrease in the $\mathrm{Mg} \#$ so that its compositions fall into the field of the rims of the groundmass olivines. The absence of other similar finds is probably due to the widespread replacement of the outer zone of rims with secondary products.

\subsubsection{Groundmass Olivines}

Groundmass olivine grains appear uniform in the BSE image (Figure 2f,g) due to weak variations in the main components. However, in terms of the microcomponents $\mathrm{Ca}, \mathrm{Ni}$, and $\mathrm{Mn}$, different trends are distinguished for the central zones and rims [39]. The central parts are characterized by weak variation in the microcomponents, a slightly positive Mg\# vs. Ni slope, and a slightly negative slope in $\mathrm{Mg \#} \mathrm{vs.} \mathrm{Cr}$ and $\mathrm{Mg \#}$ vs. Mn plots at a constant Ca content (750-1215 ppm) (Figure 4b). Compared with the central parts, the rims are characterized by a trend with a sharp increase in Ca concentration (from $930 \mathrm{ppm}$ to $2790 \mathrm{ppm}$ ), a sharp decrease in Ni concentration (from $1415 \mathrm{ppm}$ to $3695 \mathrm{ppm}$ ), and a wide spread (compared to the centers) of Cr (70-270 ppm), Zn (60-115 ppm), P (25-190 ppm). Increases in Ti (from $250 \mathrm{ppm}$ to $600 \mathrm{ppm}$ ) contents are also noted.

\subsection{Inclusions in Olivine}

Both monomineralic and melt polyphase inclusions were found in Terina olivines.

\subsubsection{Mineral Inclusions}

Only crystalline inclusions were found in the groundmass olivines, represented by small (up to $20 \mu \mathrm{m}$ ) idiomorphic grains of minerals of the spinel group (Figure $2 \mathrm{~g}$ ). Crspinels $\left(\mathrm{Cr}_{2} \mathrm{O}_{3} 18.5-26 \mathrm{wt} \%\right)$ with high $\mathrm{TiO}_{2}$ content (10-12 wt \%) were diagnosed in the central parts of the groundmass olivines with relatively low $\mathrm{Ca}$ and high $\mathrm{Ni}$ concentrations. The dominant components in these spinels are chromite and magnesiochromite (31-41\%), with lesser amounts of ulvöspinel and qandilite (15-19.5\%), magnesioferrite (10.5-24\%), magnetite (9-18\%), and spinel (6.5-11\%). Low-chromium spinels $\left(\mathrm{Cr}_{2} \mathrm{O}_{3}, 0.5-1 \mathrm{wt} \%\right)$ with high contents of magnetite (30-40\%), ulvöspinel (32-35\%), and magnesioferrite (15-16.5\%) components were identified in the rims of the groundmass olivines, which are characterized by high concentrations of $\mathrm{Ca}$ and low concentrations of $\mathrm{Ni}$ and $\mathrm{Cr}$. The trend of the spinel composition from inclusions corresponds to the "titanomagnetite" trend characteristic of orangeite and lamproite and coincides with that for spinels from Terina's groundmass UMLs [39].

Rounded ilmenite grains up to $70 \mu \mathrm{m}$ in diameter were found in the cores of the olivine macrocrysts of all groups, except for the high-Mg olivines (Figure 2h). In addition, some cores of macrocrysts of the third group contain regular intergrowths with thin ilmenite blades (Figure 2i). The ilmenites are characterized by high contents of $\mathrm{MgO}$ (5.6-11.3 wt \%) and $\mathrm{Cr}_{2} \mathrm{O}_{3}$ (up to $3.7 \mathrm{wt} \%$ ) and fall within the compositional field of kimberlite ilmenites (Figure 6a). However, they are characterized by anomalously high $\mathrm{Fe}_{2} \mathrm{O}_{3}$ contents of 3.3-16.9 wt \% (Figure 6b), which is not typical for most of the global population of kimberlites. For ilmenites, a decrease in the content of $\mathrm{TiO}_{2}$ (from 46 to $54 \mathrm{wt} \%$ ) and $\mathrm{MgO}$ and an increase in the hematite component (from $7.8 \%$ to $27 \%$ ) with an increase in the iron content of the host olivines is noted (Figure $6 \mathrm{c}$ ). The compositions of ilmenite from inclusions in olivine macrocrysts differ significantly from rare idiomorphic ilmenite grains from the groundmass of the Terina UMLs and from secondary ilmenite, which develops after $\mathrm{Cr}$-spinels and Ti-magnetite in the groundmass of rocks.

Ilmenites from the groundmass are characterized by low concentrations of $\mathrm{MgO}$ (up to $0.5 \mathrm{wt} \%$ ), $\mathrm{Cr}_{2} \mathrm{O}_{3}$ (up to $0.2 \mathrm{wt} \%$ ), and $\mathrm{Fe}_{2} \mathrm{O}_{3}$ (up to $2 \%$ ). 


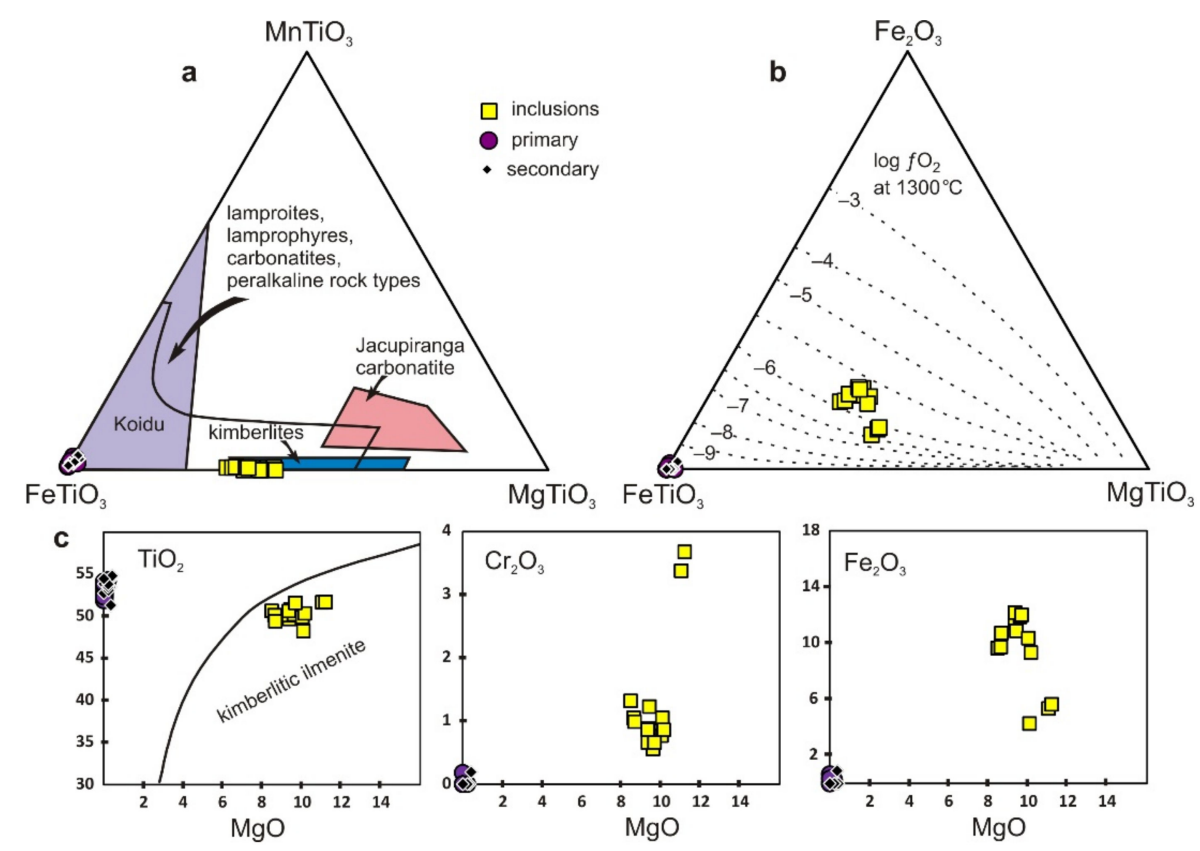

Figure 6. Ternary (a,b) and binary (c) diagrams, showing compositional variations in ilmenite inclusions ("inclusions") in olivine macrocrysts; primary ilmenites ("primary") from the groundmass of the Terina UMLs and secondary ilmenites replacing Ti-magnetite and Cr-spinels ("secondary"). Fields in (a) and $\log f \mathrm{O}_{2}$ isobars in (b) are taken from [47], kimberlite ilmenite line in (c) is after [48]. The ilmenite compositions in (c) are given in $\mathrm{wt} \% . \mathrm{Fe}_{2} \mathrm{O}_{3}$ concentrations are calculated from stoichiometry.

Single rounded inclusions of orthopyroxene with $\mathrm{Mg \#} \mathrm{87.2-87.5} \mathrm{of} \mathrm{up} \mathrm{to} 30 \mu \mathrm{m}$ were found in G2 macrocrysts (Mg\# 84-88) together with ilmenite. In addition, in several olivine macrocrysts, chains of rounded sulfide inclusions were identified, represented by intergrowths of pyrrhotite and pentlandite, which are probably decomposition products of a monosulfide solid solution (MSS) (Figure 2h).

\subsubsection{Melt and Fluid Inclusions}

Melt inclusions were found in olivine macrocrysts of all four groups, where they form chains and trace the healed cracks (Figure 7) and are interpreted as secondary. The sizes of inclusions vary greatly even within each zone (Figure 7a-f). Usually, one or more large inclusions $(10-25 \mu \mathrm{m})$ and many small ones $(<5 \mu \mathrm{m}$, more often $<2 \mu \mathrm{m})$ are present (Figure $7 \mathrm{a}, \mathrm{c}, \mathrm{f})$. The inclusions are round, oblong, or distorted in shape. All inclusions are polyphase and contain at least four different solid phases each (Figure 7j,k), and probably also a fluid phase, which is difficult to diagnose optically. The phases and their ratios for relatively large inclusions are similar within one olivine zone (Figure $7 \mathrm{a}, \mathrm{b}$ ).

In smaller inclusions of the same zone, more of the fluid phase may be present, probably due to the crystallization of refractory phases prior to the necking down of the inclusions. This allows the crystalline phases of inclusions to be considered as daughter phases. In some small inclusions, a gas bubble is clearly distinguishable (Figure 7c). The Raman spectra of such inclusions and some larger inclusions have two absorption bands of $\mathrm{CO}_{2}$ (the Fermi doublet) [49]. The difference in the frequency shifts of these peaks $(\Delta)$ depends on the $\mathrm{CO}_{2}$ density [49-51]. The $\Delta \mathrm{CO}_{2}$ for liquid and gas phases of inclusions in olivine is $104.26-104.30 \mathrm{~cm}^{-1}$, which corresponds to the densities $0.68-0.70 \mathrm{~g} / \mathrm{cm}^{3}$, according to the equation $47513.64243-1374.824414 \times \Delta \mathrm{CO}_{2}+13.25586152 \times \Delta \mathrm{CO}_{2}{ }^{2}-$ $0.04258891551 \times \Delta \mathrm{CO}_{2}{ }^{3}[50]$. 

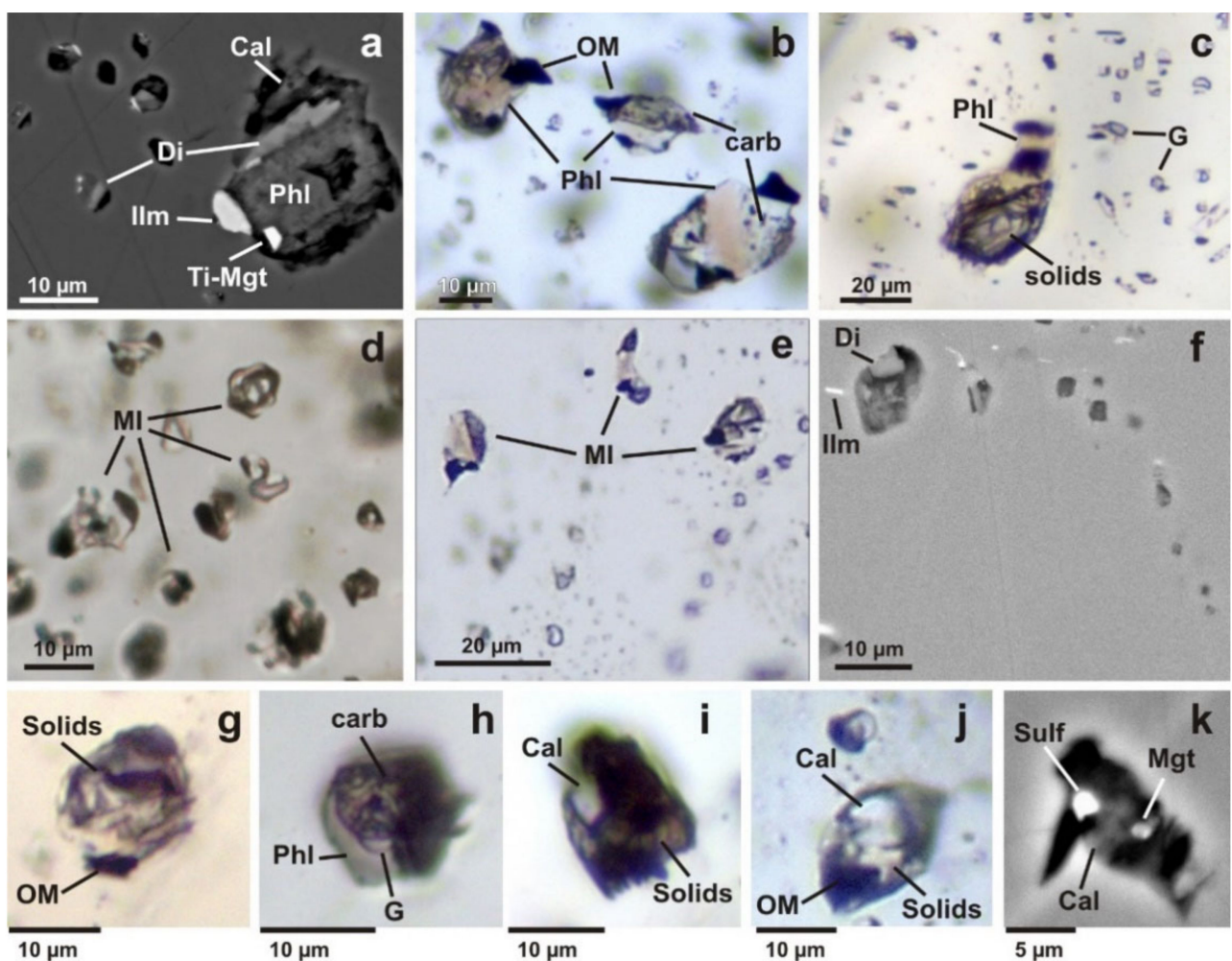

h
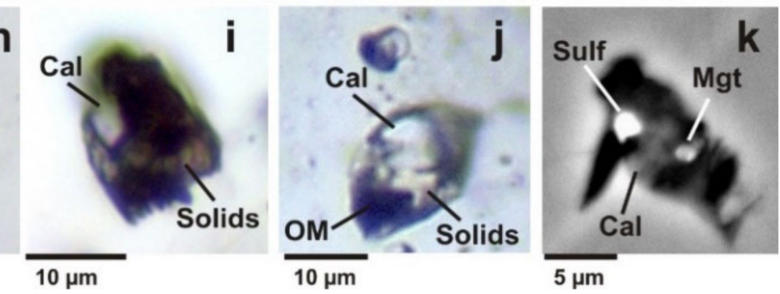

Figure 7. Microphotographs of secondary melt inclusions in olivine macrocrysts in BSE (a,f,k) and transmitted light $(\mathbf{b}-\mathbf{e}, \mathbf{g}-\mathbf{j})$. (a) Opened melt inclusions of different sizes with similar mineral compositions: phlogopite (Phl), calcite (Cal), diopside (Di), ilmenite (Ilm), and Ti-rich magnetite (Ti-Mgt); (b) non-opened melt inclusions with well-diagnosed phlogopite, several opaque phases $(\mathrm{OM})$, and a mixture of Ca-Na carbonates; (c) relatively large inclusion, with a noticeably larger amount of solid phases (solids) than in small inclusions, located in the same plane in which a gas bubble is well characterized; $(\mathbf{d}-\mathbf{f})$ chains of melt inclusions of various shapes and sizes; ( $\mathbf{g}-\mathbf{j})$ nonopened melt inclusions with different solid-phase ratios; (k) an opened inclusion containing calcite, sulfides (pentlandite and pyrrhotite) and magnetite.

Of the crystalline phases in relatively large exposed inclusions, phlogopite (Mg\# 80-84), calcite, diopside (Mg\# 72-88), and fluorapatite are most often identified. In almost all inclusions, one or more opaque phases are diagnosed, along with transparent phases. The proportion of opaque phases does not exceed $10 \mathrm{vol} \%$. The set of diagnosed opaque minerals may differ for different inclusion systems. The most typical are Ti-rich magnetite $\left(\mathrm{TiO}_{2}\right.$ up to $\left.13 \mathrm{wt} \%\right)$ and ilmenite (Figure 7a). Ilmenite from secondary inclusions in

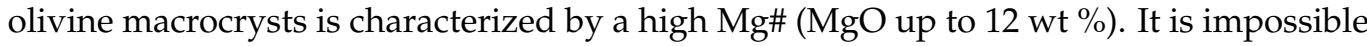
to correctly calculate its hematite component due to the small size of ilmenite. For more detail on composition of minerals from melt inclusions, see [38].

Some inclusions contain magnetite $\left(\mathrm{TiO}_{2}\right.$ up to $\left.2 \mathrm{wt} \%\right)$ or ilmenite, pentlandite, and pyrrhotite (Figure $7 \mathrm{k}$ ). In addition, Ca-amphibole, dolomite, halite, and anhydrite were diagnosed in single inclusions. Many unopened inclusions contain a fine-grained aggregate of transparent phases.

Although there are practically no high-sodium minerals in the exposed inclusions, the data obtained using LA-ICP show relatively high Na contents in all analyzed melt inclusions (Table S3 in Supplementary Materials). At the same time, for some inclusions with a high proportion of a fine-grained aggregate of transparent phases, the Na content exceeds the content of other elements (excluding $\mathrm{Si}, \mathrm{Mg}$, Fe, since these elements are also included in the host mineral). These inclusions are also characterized by the highest concentration of REE, Y, Sr, Ba, U, and Th. 
Raman spectra of unopened inclusions with a high proportion of fine-grained aggregates (Figure $8 \mathrm{a}, \mathrm{b}$ ) or consisting of colorless transparent phases (Figure $8 \mathrm{~b}-\mathrm{d}$ ) clearly show absorption lines inherent in the vibrations of $\left[\mathrm{CO}_{3}\right]$-complexes $\left(1071-1100 \mathrm{~cm}^{-1}\right)$, less often [SO $\mathrm{SO}_{4}$-complexes $\left(980-990 \mathrm{~cm}^{-1}\right)$ [49,52]. Accurate phase diagnosis is difficult because carbonates form a fine-grained aggregate of mineral phases with a grain size of $<1 \mu \mathrm{m}$, and it is not possible to isolate individual carbonate lines in the total spectrum. The absorption line at $1085-1087 \mathrm{~cm}^{-1}$ is most likely calcite, although it may also belong to alkaline carbonates; the line at 1096-1097 $\mathrm{cm}^{-1}$ may belong to dolomite; the bands at $1071-1077 \mathrm{~cm}^{-1}$ are consistent with the lines of $\mathrm{Ca}-\mathrm{Na}$ carbonates, possibly nyerereite [52,53]. Variations in the position of alkali carbonate lines can be caused by different $\mathrm{Ca}-\mathrm{Na}$ ratios or by structural features. The $1080 \mathrm{~cm}^{-1}$ line, sometimes present in the Raman spectra (Figure 8c), is the most intense peak in natrite $\mathrm{Na}_{2} \mathrm{CO}_{3}$ [54]. The fine-grained aggregate is a mixture of alkaline carbonates or carbonates and sulfates of various compositions. The absence of the $\mathrm{Na}$ and $\mathrm{Ca}-\mathrm{Na}$ carbonates in the opened inclusions is probably related to destruction upon opening or their instability in air.

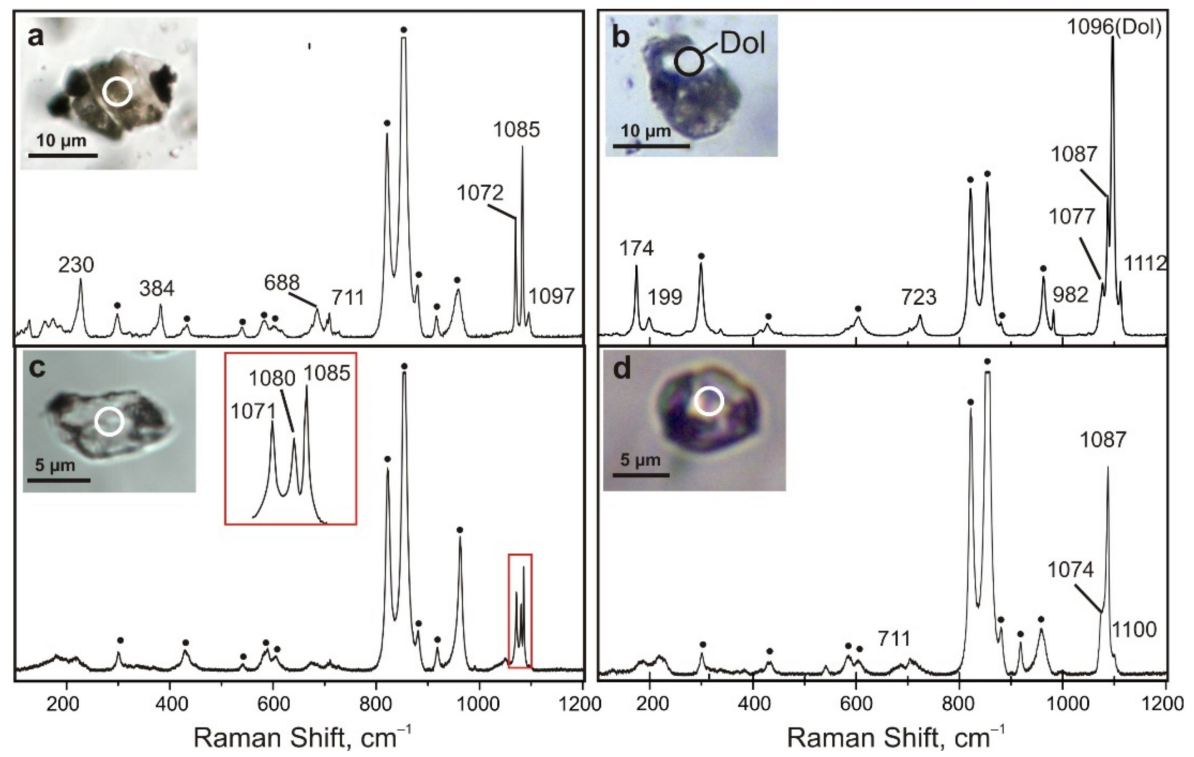

Figure 8. Raman spectra of inclusions containing many carbonate phases. Strong bands in the region of $1071-1112 \mathrm{~cm}^{-1}$ correspond to the vibrations of the $\left[\mathrm{CO}_{3}\right]$-group: bands at $1071-1077 \mathrm{~cm}^{-1}$ belong to alkaline carbonates $(\mathbf{a}-\mathbf{d})$, lines at $1086-1087 \mathrm{~cm}^{-1}$ may belong to calcite $(\mathbf{a}-\mathbf{d})$, bands at 1096-1097 $\mathrm{cm}^{-1}$ are assigned to dolomite $(\mathbf{a}, \mathbf{b})$, the band at $1080 \mathrm{~cm}^{-1}$ probably belongs to natrite (c). The line at $982 \mathrm{~cm}^{-1}$ corresponds to the vibration of the $\left[\mathrm{SO}_{4}\right]$-group $(\mathbf{b})$. The circles on the inclusion photos show the analyzed areas. Lines of host olivine on the Raman spectra are tagged by black dots under the lines of Raman.

\section{Discussion}

\subsection{Olivine Macrocrysts from the Aillikites of the Terina Complex}

The few existing works on olivines from aillikites consider only a small number of olivines to be xenocrysts. These olivines are characterized by high Mg\# (>91\%) and high $\mathrm{Ni}$ contents $(>2700 \mathrm{ppm})$ and were interpreted as mantle xenocrysts [23,24]. Olivines with reverse zoning are also present in aillikites, including those of the archetypal Aillik Bay, which have cores of Mg\# 82-84, and rims of Mg\# $(87-88)$ [8,24]. These were interpreted as having crystallized from an earlier, more evolved, ultramafic lamprophyre magma [24]. For the UMLs of the Chadobets complex, which includes Terina, it has been proposed that such macrocrysts form in small batches of aillikite melt, which crystallized at the depth of the lithospheric mantle and were subsequently uplifted by a new portion of aillikite melt [23]. 


\subsubsection{Origin of Olivine Macrocrysts}

Significant variations in macrocomponent and trace element composition are observed for the studied olivine macrocrysts from the Terina complex aillikites (Figures 4a, 5 and 9). Therefore, different sources or different evolution stages of these sources could be assumed.
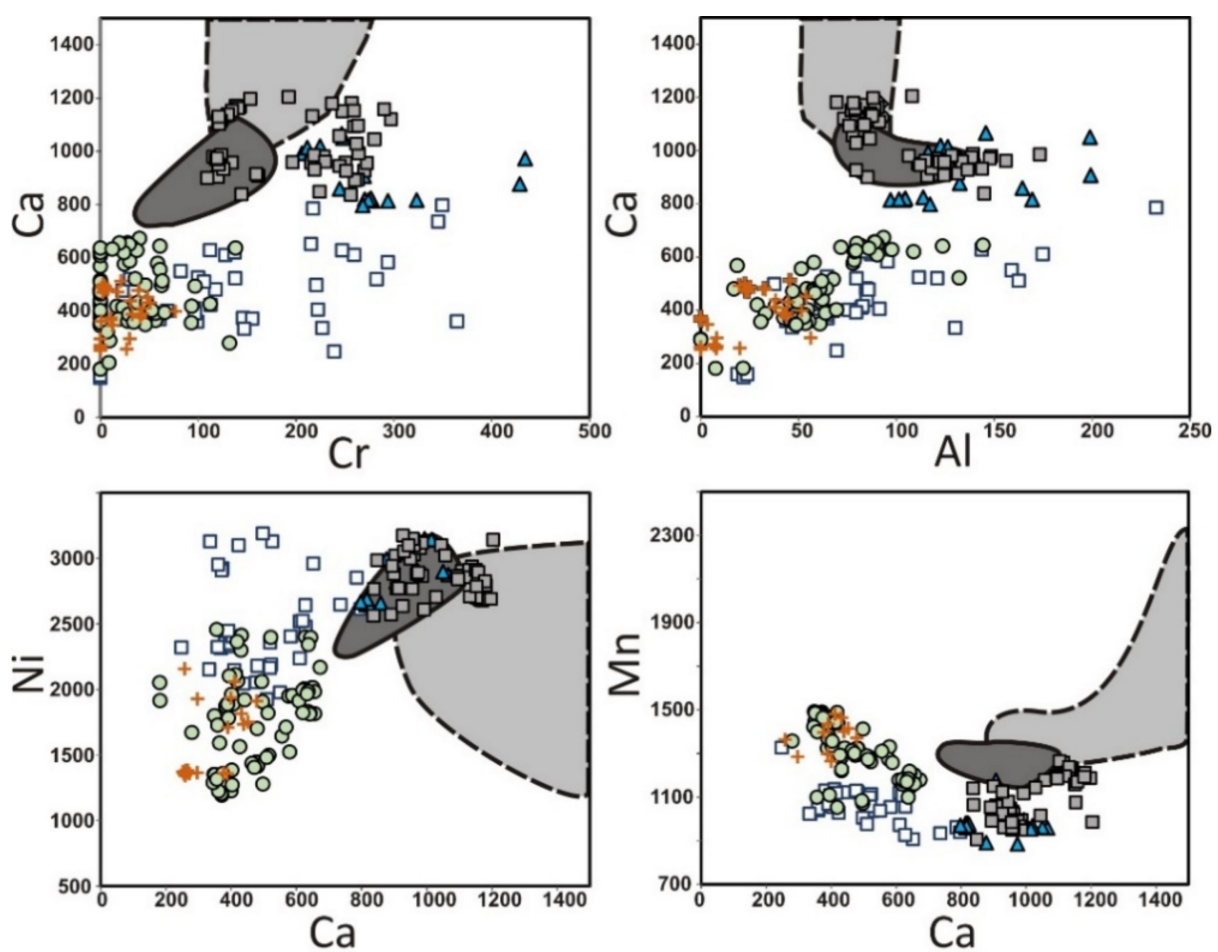

\section{$\Delta \mathrm{G} 1$ core $\square \mathrm{G} 2 \mathrm{a}$ core $\square \mathrm{G} 2 \mathrm{~b}$ core $\mathrm{O}$ G3 core + G4 core}

Figure 9. Compositional variation ( $\mathrm{ppm}$ ) of olivine macrocrysts from aillikites of the Terina complex. Legend as in Figure 4. Dark gray field-compositions of the central parts of groundmass olivines, light gray field—compositions of the rims of groundmass olivines.

High-Mg macrocrysts (G1) have the characteristics of mantle olivines: $\mathrm{Ni}>2600$ ppm, $\mathrm{Mn}<1000 \mathrm{ppm}$, and $\mathrm{Ti}<100 \mathrm{ppm}$. However, the Ca content in these macrocrysts is higher than in most olivines from mantle xenoliths $(600 \mathrm{ppm})[55,56]$. They are also characterized by relatively high $\mathrm{Al}$ contents (Figure 9). The depletion of $\mathrm{Al}$ and $\mathrm{Ca}$ in olivine is associated with the removal of $\mathrm{Ca}-\mathrm{Al}$ phases from the rocks due to the partial melting of mantle rocks [57]. Thus, we can propose that olivine macrocrysts (G1) were extracted from a slightly depleted lherzolitic mantle that did not undergo intense metasomatism. The latter assumption is based on low Ti content typical for olivines from non-metasomatized mantle peridotites.

(G2) macrocrysts are characterized by a wide scatter of trace elements. This group probably includes macrocrysts from several sources. Ca is characterized by a bimodal distribution (Figure 3b), in which two obvious trends can be distinguished: (G2a) a positive slope in Ca vs. $\mathrm{Al}$ and a negative slope in Ca vs. Mn for low-calcium macrocrysts; (G2b) a positive slope in $\mathrm{Mn}$ vs. Ca for high-calcium macrocrysts and a sharp increase in $\mathrm{Ca}$ with a decrease in $\mathrm{Al}$ (Figure 9). The $\mathbf{G} \mathbf{2} \boldsymbol{b}$ trend coincides with the trends for groundmass

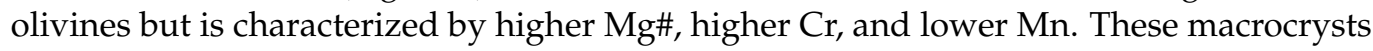
could be the cumulus phase of an earlier portion of the aillikite melt. Macrocrysts with the (G2a) trend contain inclusions of orthopyroxene and ilmenite. It has been shown that orthopyroxene is unstable (dissolves or reacts with melt) during interaction of lowsilica proto-kimberlite/proto-aillikite melts with the mantle peridotites $[45,58]$. Thus, the presence of orthopyroxene inclusions in olivine macrocrysts indicates their xenogenic nature in relation to the low-silica aillikite melt. 
Olivines significantly enriched in iron (i.e., G3, G4) are also found in kimberlites, including the kimberlites of the Siberian platform [21]. However, there are fewer of them compared to other macrocrysts. The Monastery and Colossus kimberlites (Southern African kimberlites) are exceptions, where high-Fe olivine megacrysts (grains larger than $1 \mathrm{~cm}$ ) are widespread $[22,46,59]$. The megacrysts found in these kimberlites are referred to as the Cr-poor megacryst suite [60]. They vary greatly in mineral composition and formation temperatures; however, all of them belong to high-pressure formations (4.5-6 GPa) [59,61]. In the Cr-poor megacryst suite, several paragenetic associations with olivine are discerned [59,62-64]: (1) low-Fe olivine (Mg\# 84-88\%) associates with orthopyroxene, clinopyroxene, garnet, and ilmenite (MgO 7-11 wt\%); (2) high-Fe (Mg\# 77-83\%) associates with phlogopite, ilmenite $(\mathrm{MgO}<10 \mathrm{wt} \%)$, and zircon. Making an analogy between the olivine macrocrysts of the Terina complex and the Cr-poor megacrysts suite of Southern African kimberlites, (G2a) macrocrysts correspond to the first paragenetic association of megacrysts suite with low-Fe olivine, and $(G 3, G 4)$ macrocrysts correspond to the second paragenetic association of megacrysts suite with high-Fe olivine. The presence of orthopyroxene and high-Mg ilmenite as mineral inclusions in $G 2 a$ macrocrysts and ilmenite in $\mathbf{G 3}$ and $\mathbf{G 4}$ macrocrysts enhances the similarity. Thus, we refer the olivine macrocrysts G2a, G3, and G4 to Cr-poor megacrysts suite that were disintegrated to macrocryst size when the aillikite melt rose. Olivines from the $\mathrm{Cr}$-poor megacrysts suite were also found at the Kuoika kimberlite field (Dianga, Olivinovaya, and Vtorogodnitsa pipes) at the Siberian platform [21].

\subsubsection{Geochemical Features of Olivine Macrocrysts}

Almost all the macrocrysts of the Terina olivines (except G2b) are depleted in Ca $(<1000 \mathrm{ppm})$, which strongly distinguishes them from magmatic olivines crystallizing from basic or ultrabasic magma [65], including those formed during trap magmatism [66-68]. Olivines from the Cr-poor megacryst suite are also depleted in $\mathrm{Ca}$. One of the explanations for such depletion is based on the high $\mathrm{H}_{2} \mathrm{O}$ content in the "megacryst" magma [46], which could be the reason for the decrease in $\mathrm{D}_{\mathrm{Ca}}$ olivine/melt [69]. A similar mechanism can be assumed for the olivine macrocrysts from the Terina complex.

Comparing the compositions of the (G3) and (G4) olivine macrocrysts from the Terina complex with the Fe-olivines from the Cr-poor megacryst suites of the Colossus and Monastery kimberlites, it can be seen that the latter are significantly depleted in Ni but have similar Ca and Mn contents as those of the Terina samples (Figure 10).

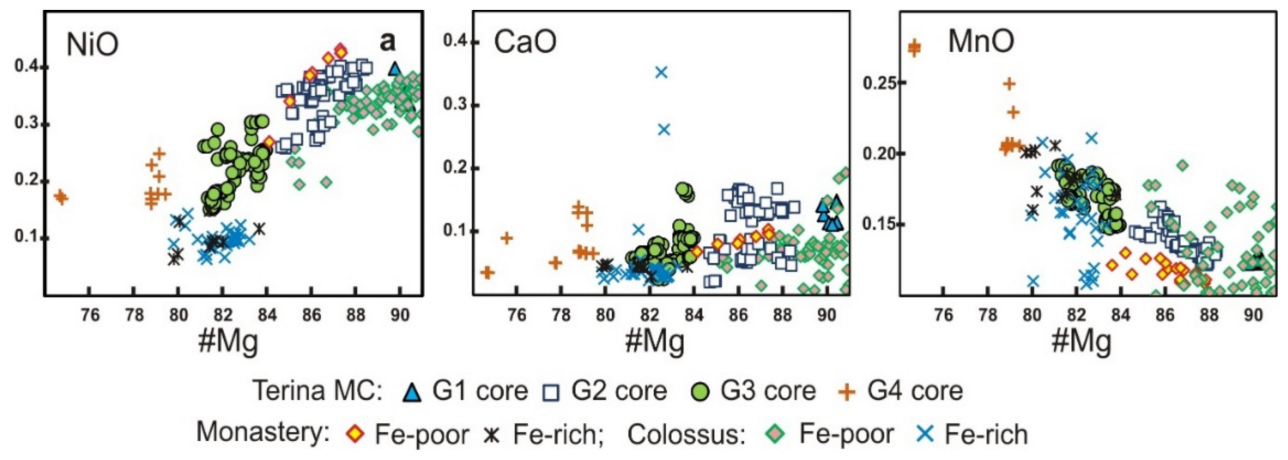

Figure 10. $\mathrm{NiO}, \mathrm{CaO}, \mathrm{MnO}(\mathrm{wt} \%)$ vs. $\mathrm{Mg} \#$ for olivine macrocrysts from the aillikites of the Terina complex, as well as for macrocrysts from the Cr-poor megacryst suite of the Colossus [22] and Monastery [46,59] kimberlites are given. Terina MC-olivine macrocrysts of Terina (legend as in Figure 4); Fe-poor: low-Fe olivines, Fe-rich: high-Fe olivines.

The positive correlation between $\mathrm{Ca}$ and $\mathrm{Al}$ is observed for the (G2a), (G3), and (G4) macrocrysts. In addition, the decreased concentration of these components coupled with Fe increase can be noticed. Such patterns can be caused by co-crystallization of olivine along with the $\mathrm{Ca}-\mathrm{Al}$ phase (likely clinopyroxene) from the melt. 


\subsubsection{Contribution of Various Mantle Sources to the Formation of Olivine Macrocrysts}

The origin of Cr-poor megacryst suite and its relationship with kimberlite melts are still debated $[22,46,70,71]$. It is believed that the Cr-poor megacryst suite is the product of the differentiation of mantle-derived magma enriched in volatiles, including water (1.8-4.2 wt \%) [59] and incompatible elements. This magma formed at the base of the sub-continental lithospheric mantle [59,62,72,73]. Researchers have also suggested a link between the parent $\mathrm{Cr}$-poor megacryst magma and recycled crystal material [46,74]. Olivine chemistry from the Cr-poor megacryst suite for Southern African kimberlites showed that "megacryst" magma resulted from melting of metasomatized peridotite with phlogopite rather than pyroxenite control in the source [46]. Pyroxenite is considered the product of the reaction of mantle peridotites with eclogite, which is recycled mafic oceanic crust.

Many researchers use the compositional features of olivine as an early liquidus phase to define the contribution of mantle and crustal material. $\mathrm{Mn} / \mathrm{Fe}, \mathrm{Ni} / \mathrm{Mg}$, as well as trace elements such as $\mathrm{Mn}, \mathrm{Li}, \mathrm{Zn}, \mathrm{Co}$, and $\mathrm{Ti}$ are used to determine the type of mantle metasomatism (e.g., carbonate, silicate) during the formation of deep melts [24,46,66,75-78].

It is assumed that olivines crystallized from peridotite-derived melt will have high $\mathrm{Mn} / \mathrm{Fe}$ and low $\mathrm{Ni} / \mathrm{Mg}$ ratios, while olivines formed from the pyroxenite-derived melt are characterized by high $\mathrm{Ni} / \mathrm{Mg}$ and lower $\mathrm{Mn} / \mathrm{Fe}$ ratios [66]. All olivine macrocrysts from the Terina aillikites have much lower $\mathrm{Mn} / \mathrm{Fe}$ ratios than peridotite-derived olivines [66] with similar Ni/Mg ratios (Figure 11). A similar Mn/Fe ratio shift for olivines from Aillik Bay aillikites was interpreted as due to the presence of phlogopite in the source [24]. The composition field of olivines from the Southern African kimberlites Cr-poor megacryst suite is also shifted towards a low $\mathrm{Mn} / \mathrm{Fe}$ ratio.

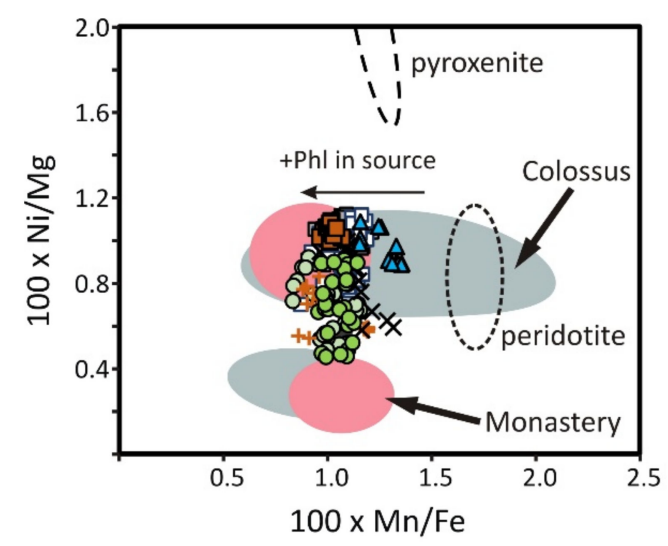

MC $\Delta \mathrm{G} 1$ core $\square \mathrm{G} 2$ core o $\mathrm{G} 3$ core $+\mathrm{G} 4$ core $\mathrm{GM} \square$ center $\times \mathrm{rim}$

Figure 11. $100 \times \mathrm{Ni} / \mathrm{Mg}$ vs. $100 \times \mathrm{Mn} / \mathrm{Fe}$ for olivine macrocrysts and groundmass olivines from the Terina complex. The compositional fields of olivine megacrysts from Monastery and Colossus kimberlites $[22,46,59]$ and the compositional fields of olivines from peridotite-derived melts and pyroxenite-derived melts [66] are given. Legend as in Figure 4.

The Mn vs. Zn ratio has been proposed to determine the contribution of peridotite and pyroxenite sources to "megacryst" magma production [78]. The compositions of the Terina olivine macrocrysts correspond to the pyroxenite trend (Figure 12a). However, the increase in $\mathrm{Zn}$ content may be related not to the melting of pyroxenite but instead may be linked to the metasomatism of the mantle source $[75,79]$. This may explain the gentler trend for olivine macrocrysts of the Terina complex compared to the pyroxenite source trend. The Li content in the olivine macrocrysts is $1-5.3 \mathrm{ppm}$ (2.6 ppm on average), which indicates a small contribution of continental crust material during the evolution of the mantle source (Figure 12b). 

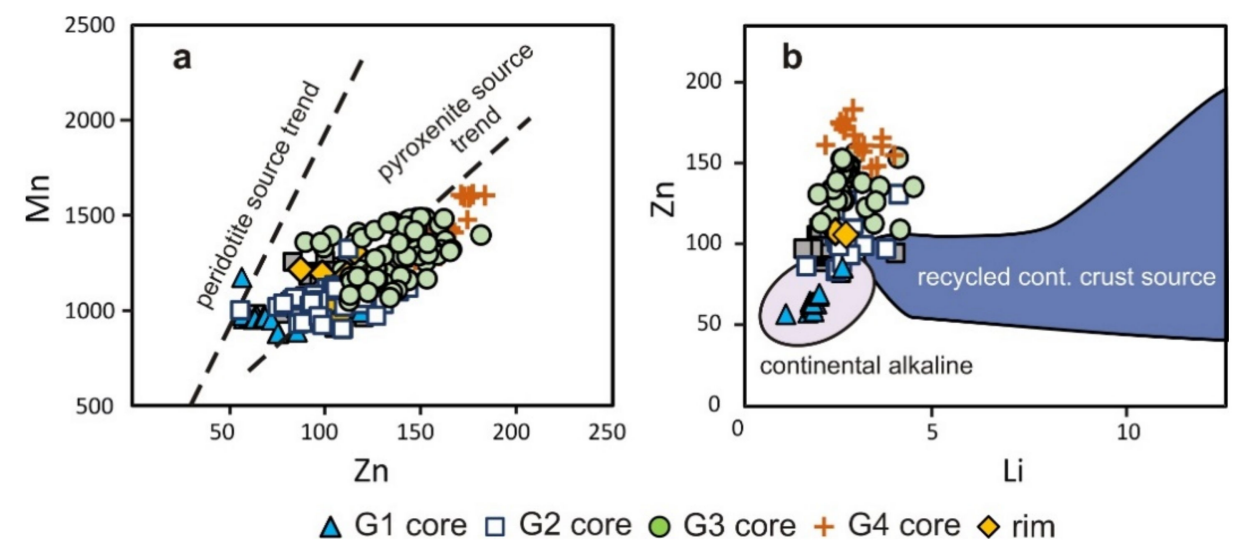

Figure 12. Mn vs. Zn (a) and Zn vs. Li (b) (ppm) for olivine macrocrysts from the Terina complex. Pyroxenite and peridotite trends are from [78]. Composition fields of recycled continental crust source and continental alkaline rocks are from [46]. Legend as in Figure 4.

\subsubsection{Ilmenite from Cr-Poor Megacryst Suite}

Monomineral ilmenite inclusions in olivine macrocrysts are characterized by high hematite component, not typical for kimberlite ilmenites. Similar $\mathrm{Fe}^{3+}$ contents were noted for ilmenites from the Koidu (Sierra Leone) [80] and Catoca, Angola kimberlites [81,82], as well as for ilmenites from Cr-poor megacryst suite of the Monastery kimberlite [83]. The high $\mathrm{Fe}^{3+}$ contents in ilmenites indicate its crystallization at a relatively high $\mathrm{fO}_{2}$ (Figure $6 \mathrm{~b}$ ), which is in good agreement with the assumption of a high $\mathrm{H}_{2} \mathrm{O}$ content in the "megacryst" magma.

It has been established that the proportion of ilmenite in the Cr-poor megacryst suite association is small, and the wide distribution of its megacrysts in kimberlites is related to the stability of ilmenite in kimberlite melt [63]. In the aillikites of Terina complex, ilmenite occurs only as inclusions in olivine macrocrysts and rarely as a late mineral replacing Ti-magnetite. If we assume that the olivine macrocrysts from Terina are part of the disintegrated Cr-poor megacryst suite, then the absence of ilmenite mega and macrocrysts in aillikites is related to its dissolution in the aillikite melt. Perhaps the dissolution of ilmenite led to an enrichment of the Ti melt and, as a consequence, a sharp increase in the Ti content in the rims of the groundmass olivines. Experiments on melting mineral associations similar to those of non-peridotitic ultrabasic veins have shown rapid melting of ilmenite, while rutile and apatite are stable up to higher temperatures [76]. The question of the nature of ilmenite from secondary melt inclusions in olivine macrocrysts remains unresolved (see Section 4.3.2).

\subsection{Groundmass Olivines}

The trace element composition of groundmass olivines of the Terina complex is characterized by higher contents of $\mathrm{Li}, \mathrm{Cu}, \mathrm{Ti}$, and $\mathrm{Na}$ compared to that of olivine macrocrysts (Figure 5). The trend for the groundmass olivines of aillikites from the Terina complex is characterized by a sharp enrichment in $\mathrm{Ca}$ and $\mathrm{Ti}$ and a rapid decrease in the $\mathrm{Ni}$ and $\mathrm{Cr}$ concentrations with a rather weak decrease in Mg\# (Figure 4). This trend replicates the trends in the compositions of olivine phenocrysts from kimberlites around the globe [55], as well as the Aillik Bay aillikites [24]. There are several explanations for the consistent $\mathrm{Mg \#}$ of olivine in the evolving kimberlite melt. First, the assimilation of orthopyroxene and other mantle minerals leads to an increase in $\mathrm{Si}$ and a decrease in the role of $\mathrm{CO}_{2}$, which decreases the olivine-melt $\mathrm{D}_{\mathrm{Fe}-\mathrm{Mg}}[15,20,84,85]$. Second, a possible reason for the constancy of the $\mathrm{Mg} \#$ of groundmass olivines is an increase in $\mathrm{fO}_{2}$, which leads to an increase in the amount of $\mathrm{Fe}^{3+}$ in the melt. $\mathrm{Fe}^{3+}$ cannot be incorporated into the olivine structure. So, despite the general increase in the Fe content in the melt, the $\mathrm{Fe}^{2+}$ content may remain at the same level or even decrease [55]. 
In the work of Nosova and colleagues [23] devoted to the UML olivines of the Chadobets complex (which includes the Terina complex), the trends of $\mathrm{Mg} / \mathrm{Fe}$ and $\mathrm{Ni}$ in olivines during the fractional crystallization of the UML were calculated. It was assumed that the $\mathrm{D}_{\mathrm{Ni}}$ and $\mathrm{D}_{\mathrm{Fe}-\mathrm{Mg}}$ between olivine and the melt would increase due to the influence of the carbonate components, which resulted in a steeper slope of the trend Mg\# vs. Ni for the fractional crystallization of olivines. A third reason for the sharp drop in $\mathrm{Ni}$ in the rims of the groundmass olivines from the aillikites of the Terina complex could be the separation of the MSS, due to which rounded segregations occur as chains of secondary crystalline inclusions in olivine macrocrysts and as opaque phases in secondary melt inclusions (Figures $2 \mathrm{~h}$ and $7 \mathrm{k}$ ). The sharp increase in $\mathrm{Ca}$ in the rims was explained [23] by the removal of $\mathrm{CO}_{2}$ from the melt, which, according to studies [86], leads to an increase in the $\mathrm{D}_{\mathrm{Ca}}$ of the olivine-melt. The decrease of the effect of $\mathrm{CO}_{2}$ can be caused by the separation of the fluid from the melt or by degassing during the rise of the aillikite melt [87]. The decrease in the $\mathrm{Cr}$ concentration in olivine is associated with the simultaneous crystallization of Cr-spinels, which are present in large amounts in the groundmass of aillikites. The increase in Ti content in groundmass olivines can be associated with the dissolution of xenogenic ilmenite in the melt.

As mentioned above, even for small groundmass olivines from kimberlites, only the rims can unambiguously be considered phenocrysts, while the central parts could represent disintegrated fragments of xenocrysts [17-19]. For the aillikites of the Terina complex, there is no compelling reason to consider the central groundmass olivine zones as xenocrysts. Moreover, mineral inclusions of $\mathrm{Cr}$-spinels were identified in the central parts of the olivines whose compositions fall within the field of $\mathrm{Cr}$-spinels from the groundmass of aillikites. This is evidence for the phenocryst nature of the central parts of the groundmass olivines. Moreover, groundmass olivines containing $\mathrm{Cr}$-spinels in the central parts and Ti-magnetite in the rims indicate that these olivines grew from the evolving aillikite melt at different stages (Figure 13a,b). For olivine zones containing Ti-magnetite, there is a sharp increase in Ca (up to $550 \mathrm{ppm}$ ) and a decrease in $\mathrm{Ni}$ (down to $900 \mathrm{ppm}$ ) compared with the central parts with inclusions of Cr-spinels (Ca, 1450-2570 ppm, Ni, 3200-1570 ppm). Olivine, along with $\mathrm{Cr}$-spinel, is a liquidus mineral. It can be assumed that the composition of the central parts of the groundmass olivine is in equilibrium with the composition of the parental aillikite melt, while its rims grew during the later stages together with the crystallization of Ti-magnetite and possibly the precipitation of MSS.

\subsection{Melt Inclusions as Indicators of Melt Evolution}

The evolution of the aillikite melt of the Terina complex can be traced using the secondary melt inclusions in the olivine macrocrysts, which were captured at different stages of the UML formation (Figure 13b-d). The composition of the earliest captured melt inclusions is similar to the composition of the groundmass of aillikites: phlogopite, diopside, calcite or dolomite, apatite with ilmenite, and Ti-magnetite. High Mg\# of ilmenite from melt inclusions differs from ilmenite from the groundmass and is similar to the kimberlite ilmenites (Figure 6) [48]. Likely, such inclusions were captured at an early stage of the evolution of the aillikite melt or higher depths, while the ilmenite of the groundmass was formed during the final stage. The formation of ilmenite in the groundmass of aillikites occurred at the final stage of the rock formation. The absence of $\mathrm{Cr}$-spinels as a daughter phases in the melt inclusions indicates that the aillikite melt was depleted in $\mathrm{Cr}$ when these inclusions were captured (Figure 13b). Thus, the inclusions were captured after crysstallization of the Cr-spinel. 


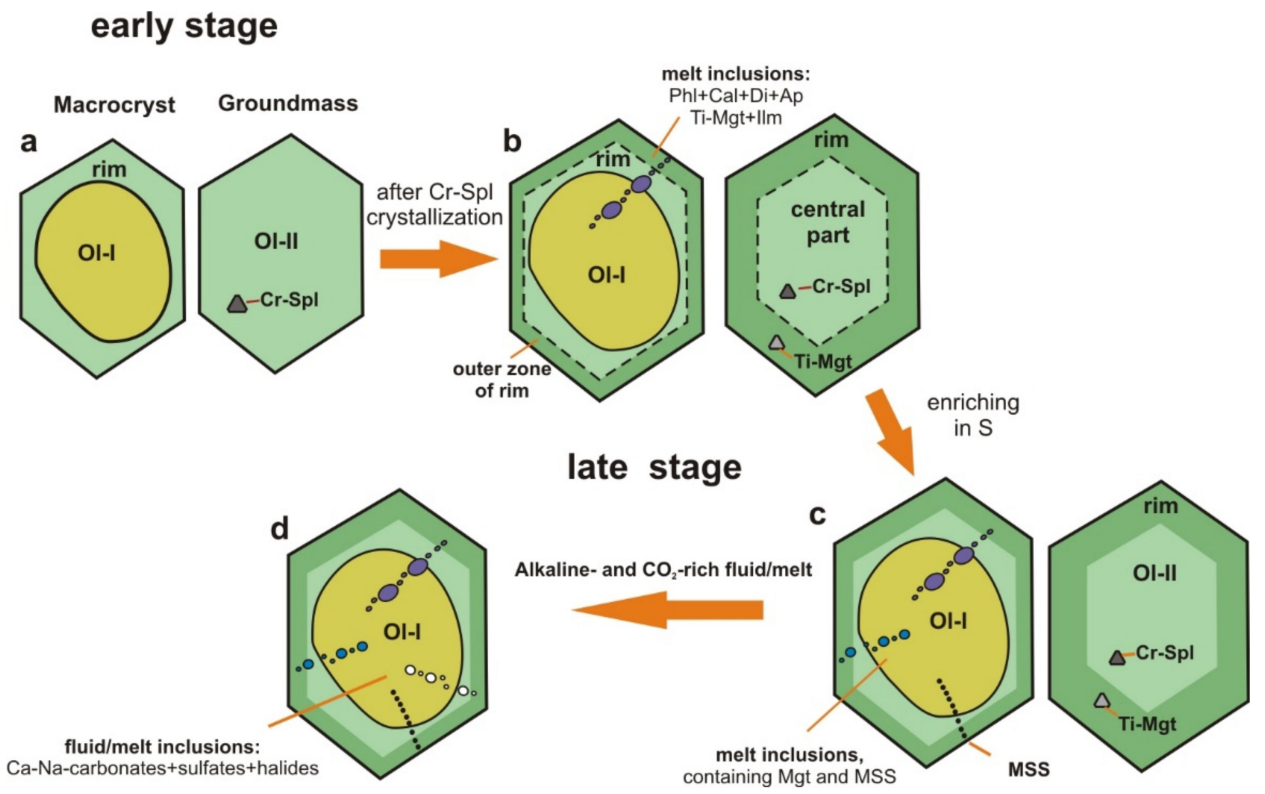

Figure 13. The scheme of olivine crystallization and trapping inclusions (mineral and melt/fluid) at different stages of aillikite melt evolution (not to scale). (a) Liquidus olivine crystallization: central part of groundmass olivines (Ol-II) and rim of the olivine macrocrysts (Ol-I), together with Cr-spinels (Cr-Spl) at the early stage of aillikite formation. (b) Crystallization of olivine groundmass rims and capture of Ti-rich magnetite grains (Ti-Mgt); penetration of aillikite melt through fissures in the olivine macrocrysts with the subsequent formation of the secondary melt inclusions of phlogopite (Phl), calcite (Cal), diopside (Di), apatite (Ap), Ti-rich magnetite and ilmenite (Ilm). (c) Capture of S-enriched melt by macrocrysts at the late stage of aillikite evolution, and the formation of melt and mineral inclusions containing monosulfide solution (MSS) (pyrrhotite and pentlandite). (d) Trapping of inclusions, which mainly consists of alkaline carbonates and sulfates at the last stage of the aillikites formation.

Sulfide-containing inclusions with magnetite appear to have been captured at a later stage, when the residual melt was sufficiently enriched in S, which led to the precipitation of MSS from the melt (Figure 13c). Despite the absence of Na phases in the groundmass of the aillikites and their insignificant presence in the opened melt inclusions, ICP-LA and Raman studies of non-opened inclusions revealed high $\mathrm{Na}$ concentrations in excess of the $\mathrm{K}$ content, as well as the presence of alkaline carbonate aggregates. It can be assumed that the aillikite melts were significantly enriched in Na; however, the Na phases that crystallized in the groundmass - carbonates, sulfates, and possibly halides-were extremely unstable and dissolved. The inclusions, which mainly consist of alkaline carbonates and sulfates, and are enriched in incompatible elements (U, Th, REE, Y, Sr, and Ba), were captured at the last stage of the formation of aillikites (Figure 13d). It is possible that melts of similar composition were separated during the carbonate-silicate immiscibility, but no evidence of this process could be found in the inclusions.

\subsection{Genetic Relationship Between Olivine Macrocrysts and UMLs}

Within the Irkineeva-Chadobets Trough, in addition to the Chadobets complex (which includes the Terina complex) formed in the post-trap period, there is another UML complex: Ilbokich (Figure 1), which is a product of pre-trap magmatism. Detailed studies of the isotopic characteristics of these complexes showed that the melts had a predominant moderately depleted mantle source with the addition of the material from the SCLM [31,32]. It was concluded that the SCLM source involved in the magma generation of the complexes changed over time. Metasomes containing hydrous minerals (phlogopite or amphibole) from the base of the lithosphere made a significant contribution during the formation of the Ilbokich complex. These metasomes may have formed during the Caledonian 
collision [88] because of the input of volatile-rich crustal material into mantle peridotites, which react with peridotites and form phlogopite-rich assemblages. The influence of phlogopite metasomes was significantly less for the post-trap UMLs of the Chadobets complex, while the contribution of carbonate metasomatism increased [32].

It is widely believed that the formation of the megacryst suites is associated with lithospheric mantle metasomatism that occurs immediately before the uplift of kimberlite magma [55,74,89-91]. As mentioned above, the Cr-poor megacryst suite is formed at pressures of 4.5-6 GPa [22,46,59], and it is assumed that the volatile-rich melts are involved [46,59]. By analogy with the Southern African Cr-poor megacryst suite [46], the formation of the Terina complex olivine macrocrysts (supposedly a disintegrated megacryst suite) could have occurred during the melting of the SCLM that contains phlogopite metasomes at the bottom of the Siberian platform. The melting could cause the formation of volatile-rich melts that could then migrate to shallower depths, forming veins in the SCLM. This process could occur together with the formation of the Ilbokich pre-trap complex, for which a predominantly phlogopite metasome agent is also assumed [23,32].

Thus, the olivine macrocrysts (G2a, G3, and G4), probably formed due to partial melting of the metasomatized mantle in the pre-trap period and subsequently in the post-trap period, were transported as xenocrysts by the aillikite melt.

\section{Conclusions}

Olivines from the aillikites of the Terina complex are divided into groundmass olivines, which are phenocrysts, and macrocrysts for which the polygenetic nature of formation was established. Groundmass olivines are characterized by higher concentrations of $\mathrm{Li}, \mathrm{Cu}$, $\mathrm{Ti}$, and Na compared with olivine macrocrysts. They have a trend that includes a sharp increase in $\mathrm{Ca}$ and $\mathrm{Ti}$ contents and depletion in $\mathrm{Ni}$ and $\mathrm{Cr}$ concentration from the center to the rim that can be explained by the crystallization conditions (precipitation of MSS from the melt, dissolution of xenogenic orthopyroxene and ilmenite, degassing with the removal of $\mathrm{CO}_{2}$ from the melt).

The olivine macrocrysts are divided into four groups according to $\mathrm{Mg \#}$. The first group is probably olivines from xenoliths of the weakly depleted lherzolite mantle. Macrocrysts of the second group have high-Ca and low-Ca compositional evolution trends. The highCa macrocrysts are probably the cumulus phase of earlier portions of the aillikite melt. Macrocrysts with a low-Ca trend, as well as the high-Fe macrocrysts of the third and fourth groups, could be disintegrated megacrysts from the Cr-poor megacryst suite. It is possible that the megacryst suite was formed during the melting of the metasomatized subcontinental lithospheric mantle, where phlogopite was the metasomatic agent.

The secondary melt inclusions in olivine macrocrysts reflect the composition of the evolving aillikite melt. In addition to phlogopite, diopside, calcite, apatite, and opaque phases (Ti-rich magnetite, ilmenite, magnetite, pentlandite, and pyrrhotite), alkaline carbonates and sulfates were identified. The proportion of the latter along with concentrations of rare elements ( $\mathrm{U}, \mathrm{Th}, \mathrm{Y}, \mathrm{REE}, \mathrm{Sr}$, and $\mathrm{Ba}$ ) increased with the evolution of the melt.

Supplementary Materials: The following are available online at https://www.mdpi.com/article/10 $.3390 / \mathrm{min} 11040408 / \mathrm{s} 1$, Table S1. Chemical composition of olivines from Terina aillikites (WDS, EDS). Table S2. Trace element composition of olivines from Terina aillikites (ICP-LA). Table S3. Composition of secondary inclusions from olivine macrocrysts obtained using ICP-LA.

Author Contributions: Conceptualization, A.S., A.D.; data curation, A.S.; investigation, A.S., I.P., A.R. and V.C.; methodology, A.S., I.P.; project administration, I.P.; writing-original draft, A.S.; writing-review and editing, A.S., I.P. and A.D. All authors have read and agreed to the published version of the manuscript.

Funding: The investigations were supported by the Russian Science Foundation (RSF), project \#1977-10004.

Data Availability Statement: The data presented in the article is available in Supplementary Materials. 
Acknowledgments: The authors express their sincere appreciation to the editors and reviewers for their contributions to improving the manuscript. The analytical equipment used in this study was provided by the Analytical Center for multi-elemental and isotope research SB RAS, Novosibirsk, Russia. Determination of the microelement composition of the LA-ICP-MS at IGG UB RAS was carried out in the Common Use Center of the Ural Branch of RAS "Geoanalyst" within the framework of the topic No. AAAA-A18-118053090045-8. The work was done as a state assignment of IGM SB RAS (IX.125.2 and 0330-2016-0002) and GIN SB RAS No. AAAA-A21-121011390002-2.

Conflicts of Interest: The authors declare no conflict of interest.

\section{References}

1. Tappe, S.; Foley, S.F.; Jenner, G.A.; Kjarsgaard, B.A. Integrating Ultramafic Lamprophyres into the IUGS Classification of Igneous Rocks: Rationale and Implications. J. Petrol. 2005, 46, 1893-1900. [CrossRef]

2. Foley, S.F.; Andronikov, A.V.; Melzer, S. Petrology of ultramafic lamprophyres from the Beaver Lake area of Eastern Antarctica and their relation to the breakup of Gondwanaland. Miner. Petrol. 2002, 74, 361-384. [CrossRef]

3. Kjarsgaard, B.; Pearson, D.; Tappe, S.; Nowell, G.; Dowall, D. Geochemistry of hypabyssal kimberlites from Lac de Gras, Canada: Comparisons to a global database and applications to the parent magma problem. Lithos 2009, 112, 236-248. [CrossRef]

4. Tappe, S.; Jenner, G.A.; Foley, S.F.; Heaman, L.; Besserer, D.; Kjarsgaard, B.A.; Ryan, B. Torngat ultramafic lamprophyres and their relation to the North Atlantic Alkaline Province. Lithos 2004, 76, 491-518. [CrossRef]

5. Le Roex, A.P.; Bell, D.R.; Davis, P. Petrogenesis of Group I Kimberlites from Kimberley, South Africa: Evidence from Bulk-rock Geochemistry. J. Petrol. 2003, 44, 2261-2286. [CrossRef]

6. Kamenetsky, V.S.; Grütter, H.; Kamenetsky, M.B.; Gömann, K. Parental carbonatitic melt of the Koala kimberlite (Canada): Constraints from melt inclusions in olivine and Cr-spinel, and groundmass carbonate. Chem. Geol. 2013, 353, 96-111. [CrossRef]

7. Francis, D.; Patterson, M. Kimberlites and aillikites as probes of the continental lithospheric mantle. Lithos 2009, 109, 72-80. [CrossRef]

8. Tappe, S.; Foley, S.F.; Jenner, G.A.; Heaman, L.M.; Kjarsgaard, B.A.; Romer, R.L.; Stracke, A.; Joyce, N.; Hoefs, J. Genesis of Ultramafic Lamprophyres and Carbonatites at Aillik Bay, Labrador: A Consequence of Incipient Lithospheric Thinning beneath the North Atlantic Craton. J. Petrol. 2006, 47, 1261-1315. [CrossRef]

9. Tappe, S.; Foley, S.F.; Stracke, A.; Romer, R.L.; Kjarsgaard, B.A.; Heaman, L.M.; Joyce, N. Craton reactivation on the Labra-dor Sea margins: 40Ar/39Ar age and $\mathrm{Sr}-\mathrm{Nd}-\mathrm{Hf}-\mathrm{Pb}$ isotope constraints from alkaline and carbonatite intrusives. Earth Planet. Sci. Lett. 2007, 256, 433-454. [CrossRef]

10. Mitchell, R.; Tappe, S. Discussion of "kimberlites and aillikites as probes of the continental lithospheric mantle", by D. Francis and M. Patterson (Lithos v. 109, p. 72-80). Lithos 2010, 115, 288-292. [CrossRef]

11. Armstrong, J.P.; Wilson, M.; Barnett, R.L.; Nowicki, T.; Kjarsgaard, B.A. Mineralogy of primary carbonate-bearing hypabyssal kimberlite, Lac de Gras, Slave Province, Northwest Territories, Canada. Lithos 2004, 76, 415-433. [CrossRef]

12. Chakhmouradian, A.R.; Reguir, E.P.; Kamenetsky, V.S.; Sharygin, V.V.; Golovin, A.V. Trace-element partitioning in perovskite: Implications for the geochemistry of kimberlites and other mantle-derived undersaturated rocks. Chem. Geol. 2013, 353, 112-131. [CrossRef]

13. Giuliani, A.; Phillips, D.; Kamenetsky, V.S.; Goemann, K. Constraints on kimberlite ascent mechanisms revealed by phlogopite compositions in kimberlites and mantle xenoliths. Lithos 2016, 240-243, 189-201. [CrossRef]

14. Sobolev, N.; Tomilenko, A.; Kovyazin, S.; Batanova, V.; Kuz'Min, D. Paragenesis and complex zoning of olivine macrocrysts from unaltered kimberlite of the Udachnaya-East pipe, Yakutia: Relationship with the kimberlite formation conditions and evolution. Russ. Geol. Geophys. 2015, 56, 260-279. [CrossRef]

15. Kamenetsky, V.S.; Kamenetsky, M.B.; Sobolev, A.V.; Golovin, A.V.; Demouchy, S.; Faure, K.E.; Sharygin, V.V.; Kuzmin, D.V. Olivine in the Udachnaya-East Kimberlite (Yakutia, Russia): Types, Compositions and Origins. J. Petrol. 2007, 49, 823-839. [CrossRef]

16. Fedortchouk, Y. Intensive Variables in Kimberlite Magmas, Lac de Gras, Canada and Implications for Diamond Survival. J. Petrol. 2004, 45, 1725-1745. [CrossRef]

17. Arndt, N.T.; Guitreau, M.; Boullier, A.-M.; Le Roex, A.; Tommasi, A.; Cordier, P.; Sobolev, A. Olivine, and the Origin of Kimberlite. J. Petrol. 2010, 51, 573-602. [CrossRef]

18. Arndt, N.T.; Boullier, A.M.; Clement, J.P.; Dubois, M.; Schissel, D. What olivine, the neglected mineral, tells us about kim-berlite petrogenesis. eEarth Discuss. 2006, 1, 37-50. [CrossRef]

19. Brett, R.; Russell, J.; Moss, S. Origin of olivine in kimberlite: Phenocryst or impostor? Lithos 2009, 112, 201-212. [CrossRef]

20. Bussweiler, Y.; Foley, S.F.; Prelević, D.; Jacob, D.E. The olivine macrocryst problem: New insights from minor and trace element compositions of olivine from Lac de Gras kimberlites, Canada. Lithos 2015, 220-223, 238-252. [CrossRef]

21. Tychkov, N.S.; Agashev, A.M.; Pokhilenko, N.P.; Tsykh, V.A.; Sobolev, N.V. Types of Xenogenic Olivine from Siberian Kimberlites. Minerals 2020, 10, 302. [CrossRef]

22. Moore, A.; Costin, G. Kimberlitic olivines derived from the Cr-poor and Cr-rich megacryst suites. Lithos 2016, 258-259, 215-227. [CrossRef] 
23. Nosova, A.A.; Sazonova, L.V.; Kargin, A.V.; Smirnova, M.D.; Lapin, A.V.; Shcherbakov, V.D. Olivine in ultramafic lamprophyres: Chemistry, crystallisation, and melt sources of Siberian Pre- and post-trap aillikites. Contrib. Miner. Petrol. 2018, 173, 55. [CrossRef]

24. Veter, M.; Foley, S.F.; Mertz-Kraus, R.; Groschopf, N. Trace elements in olivine of ultramafic lamprophyres controlled by phlogopite-rich mineral assemblages in the mantle source. Lithos 2017, 292-293, 81-95. [CrossRef]

25. Wang, C.; Zhang, Z.; Giuliani, A.; Cheng, Z.; Liu, B.; Kong, W. Geochemical and O-C-Sr-Nd Isotopic Constraints on the Petrogenetic Link between Aillikites and Carbonatites in the Tarim Large Igneous Province. J. Petrol. 2021, 2021a, egab017. [CrossRef]

26. Wang, C.H.; Zhang, Z.C.; Xie, Q.H.; Cheng, Z.G.; Kong, W.L.; Liu, B.X.; Santosh, M.; Jin, S.K. Olivine from aillikites in the Tarim large igneous province as a window into mantle metasomatism and multi-stage magma evolution. Am. Miner. 2020. [CrossRef]

27. Kirichenko, T.; Zuev, K.; Perfilova, O.Y.; Sosnovskaya, O.; Smokotina, I.; Markovich, L.A.; Borodin, M.E. State Geological Map of Russian Federation, Scale 1:1000000 (Third Generation). Ser. Angaro-Eniseysk. Sheet O-47 Bratsk. Explanatory Note; Cartografic Factory of VSEGEI: St. Petersburg, Russian, 2012; pp. 163-179. (In Russian)

28. Dashkevich, N.N. Regional prediction of kimberlite magmatism in the southwestern Siberian Platform. Geologiya $i$ Poleznye Iskopaemye Krasnoyarskogo Kraya 1999, 1-4. (In Russian)

29. Starosel'Tsev, V. Identifying paleorifts as promising tectonic elements for active oil and gas generation. Russ. Geol. Geophys. 2009, 50, 358-364. [CrossRef]

30. Doroshkevich, A.; Sharygin, V.; Belousova, E.; Izbrodin, I.; Prokopyev, I. Zircon from the Chuktukon alkaline ultramafic carbonatite complex (Chadobets uplift, Siberian craton) as evidence of source heterogeneity. Lithos 2021, 382-383, 105957. [CrossRef]

31. Doroshkevich, A.G.; Chebotarev, D.A.; Sharygin, V.V.; Prokopyev, I.R.; Nikolenko, A.M. Petrology of alkaline silicate rocks and carbonatites of the Chuktukon massif, Chadobets upland, Russia: Sources, evolution and relation to the Triassic Siberian LIP. Lithos 2019, 332-333, 245-260. [CrossRef]

32. Nosova, A.A.; Kargin, A.V.; Sazonova, L.V.; Dubinina, E.O.; Chugaev, A.V.; Lebedeva, N.M.; Yudin, D.S.; Larionova, Y.O.; Abersteiner, A.; Gareev, B.I.; et al. Sr-Nd-Pb isotopic systematic and geochronology of ultramafic alkaline magmatism of the southwestern margin of the Siberian Craton: Metasomatism of the sub-continental lithospheric mantle related to subduction and plume events. Lithos 2020, 364-365, 105509. [CrossRef]

33. Chebotarev, D.; Doroshkevich, A.; Sharygin, V.; Yudin, D.; Ponomarchuk, A.; Sergeev, S. Geochronology of the Chuktukon carbonatite massif, Chadobets uplift (Krasnoyarsk Territory). Russ. Geol. Geophys. 2017, 58, 1222-1231. [CrossRef]

34. Lapin, A.V.; Lisitsin, D.V. On the mineralogical typomorphism of alkaline ultrabasic migmatites of the Chadobets ulift. Otechestvennaya Geol. 2004, 6, 83-92. (In Russian)

35. Lapin, A.V.; Pyatenko, I.K. Chadobets complex of ultrabasic alkaline rocks and carbonatites: New data about composition and condition of formation. Dokl. Earth Sci. 1992, 6, 88-101. (In Russian)

36. Slukin, A.D. Bauxite Deposits with Unusually High Concentrations of REE, Nb, Ti, and Th, Chadobets Uplift, Siberian Platform. Int. Geol. Rev. 1994, 36, 179-193. [CrossRef]

37. Pernet-Fisher, J.; Howarth, G.; Pearson, D.; Woodland, S.; Barry, P.; Pokhilenko, N.; Pokhilenko, L.; Agashev, A.; Taylor, L. Plume impingement on the Siberian SCLM: Evidence from Re-Os isotope systematics. Lithos 2015, 218-219, 141-154. [CrossRef]

38. Prokopyev, I.; Starikova, A.; Doroshkevich, A.; Nugumanova, Y.; Potapov, V. Petrogenesis of Ultramafic Lamprophyres from the Terina Complex (Chadobets Upland, Russia): Mineralogy and Melt Inclusion Composition. Minerials 2020, 10, 419. [CrossRef]

39. Scott Smith, B.H.; Nowicki, T.E.; Russell, J.K.; Webb, K.J.; Mitchell, R.H.; Hetman, C.M.; Harder, M.; Skinner, E.M.W.; Robey, J.A. Kimberlite Terminology and Classification. In Proceedings of the 10th International Kimberlite Conference, Bangalore, India, 5-11 February 2012; pp. 1-17.

40. Longerich, H.P.; Jackson, S.E.; Günther, D. Inter-laboratory note. Laser ablation inductively coupled plasma mass spectrometric transient signal data acquisition and analyte concentration calculation. J. Anal. At. Spectrom. 1996, 11, 899-904. [CrossRef]

41. Günther, D.; Audétat, A.; Frischknecht, R.; Heinrich, C.A. Quantitative analysis of major, minor and trace elements in fluid inclusions using laser ablation-inductively coupled plasmamass spectrometry. J. Anal. At. Spectrom. 1998, 13, 263-270. [CrossRef]

42. Ulrich, T.; Günther, D.; Heinrich, C.A. The Evolution of a Porphyry Cu-Au Deposit, Based on LA-ICP-MS Analysis of Fluid Inclusions: Bajo de la Alumbrera, Argentina. Econ. Geol. 2002, 97, 1889-1920. [CrossRef]

43. Heinrich, C.; Pettke, T.; Halter, W.; Aigner-Torres, M.; Audétat, A.; Günther, D.; Hattendorf, B.; Bleiner, D.; Guillong, M.; Horn, I. Quantitative multi-element analysis of minerals, fluid and melt inclusions by laser-ablation inductively-coupled-plasma mass-spectrometry. Geochim. Cosmochim. Acta 2003, 67, 3473-3497. [CrossRef]

44. Prokopyev, I.R.; Borisenko, A.S.; Borovikov, A.A.; Pavlova, G.G. Origin of REE-rich ferrocarbonatites in southern Siberia (Russia): Implications based on melt and fluid inclusions. Miner. Petrol. 2016, 110, 845-859. [CrossRef]

45. Cordier, C.; Sauzeat, L.; Arndt, N.T.; Boullier, A.-M.; Batanova, V.; Barou, F. Metasomatism of the Lithospheric Mantle Immediately Precedes Kimberlite Eruption: New Evidence from Olivine Composition and Microstructures. J. Petrol. 2015, 56, 1775-1796. [CrossRef]

46. Howarth, G.H. Olivine megacryst chemistry, Monastery kimberlite: Constraints on the mineralogy of the HIMU mantle reservoir in southern Africa. Lithos 2018, 314-315, 658-668. [CrossRef]

47. Haggerty, S.E. Chapter 10-Oxide mineralogy of the upper mantle. Oxide Miner. Mineral. Soc. Am. Rev. Mineral. 1991, 25, 355-416. [CrossRef] 
48. Wyatt, B.A.; Baumgartner, M.; Anckar, E.; Grutter, H. Compositional classification of "kimberlitic" and "non-kimberlitic" ilmenite. Lithos 2004, 77, 819-840. [CrossRef]

49. Frezzotti, M.L.; Tecce, F.; Casagli, A. Raman spectroscopy for fluid inclusion analysis. J. Geochem. Explor. 2012, 112, 1-20. [CrossRef]

50. Wang, X.; Chou, I.-M.; Hu, W.; Burruss, R.C.; Sun, Q.; Song, Y. Raman spectroscopic measurements of CO2 density: Experimental calibration with high-pressure optical cell (HPOC) and fused silica capillary capsule (FSCC) with application to fluid inclusion observations. Geochim. Cosmochim. Acta 2011, 75, 4080-4093. [CrossRef]

51. Lamadrid, H.; Moore, L.; Moncada, D.; Rimstidt, J.; Burruss, R.; Bodnar, R. Reassessment of the Raman $\mathrm{CO}_{2}$ densimeter. Chem. Geol. 2017, 450, 210-222. [CrossRef]

52. Shatskiy, A.; Gavryushkin, P.N.; Litasov, K.D.; Koroleva, O.N.; Kupriyanov, I.N.; Borzdov, Y.M.; Sharygin, I.S.; Funakoshi, K.; Palyanov, Y.N.; Ijiohtani, E. Na-Ca carbonates synthesized under upper-mantle conditions: Raman spectroscopic and X-ray diffraction studies. Eur. J. Miner. 2015, 27, 175-184. [CrossRef]

53. Zaitsev, A.N.; Keller, J.; Spratt, J.; Jeffries, T.E.; Sharygin, V.V. Chemical composition of nyerereite and gregoryite from natrocarbonatites of Oldoinyo Lengai volcano, Tanzania. Geol. Ore Deposits 2009, 51, 608-616. [CrossRef]

54. Buzgar, N.; Apopei, A.I. The Raman study on certain carbonates. Geoarheology 2009, 55, 97-112.

55. Giuliani, A. Insights into kimberlite petrogenesis and mantle metasomatism from a review of the compositional zoning of olivine in kimberlites worldwide. Lithos 2018, 312-313, 322-342. [CrossRef]

56. Foley, S.F.; Prelevic, D.; Rehfeldt, T.; Jacob, D.E. Minor and trace elements in olivines as probes into early igneous and mantle melting processes. Earth Planet. Sci. Lett. 2013, 363, 181-191. [CrossRef]

57. Boyd, F. Compositional distinction between oceanic and cratonic lithosphere. Earth Planet. Sci. Lett. 1989, 96, 15-26. [CrossRef]

58. Sharygin, I.S.; Litasov, K.D.; Shatskiy, A.; Safonov, O.G.; Golovin, A.V.; Ohtani, E.; Pokhilenko, N.P. Experimental constraints on orthopyroxene dissolution in alkali-carbonate melts in the lithospheric mantle: Implications for kimberlite melt composition and magma ascent. Chem. Geol. 2017, 455, 44-56. [CrossRef]

59. Bell, D.R.; Rossman, G.R.; Moore, R.O. Abundance and Partitioning of OH in a High-pressure Magmatic System: Megacrysts from the Monastery Kimberlite, South Africa. J. Petrol. 2004, 45, 1539-1564. [CrossRef]

60. Eggler, D.H.; McCallum, M.E.H.; Smith, C.B.H. Megacryst assemblages in kimberlite from northern Colorado and southern Wyoming: Petrology, geothermometry-barometry, and areal distribution. In The Mantle Sample: Inclusion in Kimberlites and Other Volcanics; American Geophysical Union (AGU): Washington, DC, USA, 1979; pp. 213-226.

61. Moore, R.O. A Study of the Kimberlites, Diamonds and Associated Rocks and Minerals from the Monastery Mine, South Af-rica. Ph.D. Thesis, University of Cape Town, Cape Town, South Africa, 1986.

62. Gurney, J.J.; Jakob, W.R.O.; Dawson, J.B. Megacrysts from the Monastery Kimberlite Pipe, South Africa. In The Mantle Sample: Inclusion in Kimberlites and Other Volcanics; American Geophysical Union (AGU): Washington, DC, USA, 1979; pp. $227-243$.

63. Moore, R.; Griffin, W.L.; Gurney, J.; Ryan, C.; Cousens, D.; Sie, S.; Suter, G. Trace element geochemistry of ilmenite megacrysts from the Monastery kimberlite, South Africa. Lithos 1992, 29, 1-18. [CrossRef]

64. Hatton, C.J. The kimberlite-megacryst link at the Monastery Mine. Extended Abstracts. In Proceedings of the 7th International Kimberlite Conference, Cape Town, South Africa, 11-17 April 1998; pp. 314-316.

65. Köhler, T.; Brey, G. Calcium exchange between olivine and clinopyroxene calibrated as a geothermobarometer for natural peridotites from 2 to $60 \mathrm{~kb}$ with applications. Geochim. Cosmochim. Acta 1990, 54, 2375-2388. [CrossRef]

66. Sobolev, A.V.; Hofmann, A.W.; Kuzmin, D.V.; Yaxley, G.M.; Arndt, N.T.; Chung, S.-L.; Danyushevsky, L.V.; Elliott, T.; Frey, F.A.; Garcia, M.O.; et al. The amount of recycled crust in sources of mantle-derived melts. Science 2007, 316, 412-417. [CrossRef]

67. Sobolev, A.; Kuzmin, D.; Malitch, K.; Petrunin, A. Siberian meimechites: Origin and relation to flood basalts and kimberlites. Russ. Geol. Geophys. 2009, 50, 999-1033. [CrossRef]

68. Sobolev, A.V.; Krivolutskaya, N.A.; Kuzmin, D.V. Petrology of the parental melts and mantle sources of Siberian trap magmatism. Petrology 2009, 17, 253-286. [CrossRef]

69. Gavrilenko, M.; Herzberg, C.; Vidito, C.; Carr, M.J.; Tenner, T.; Ozerov, A. A calcium-in-olivine geohygrometer and its ap-plication to subduction zone magmatism. J. Petrol. 2016, 57, 1811-1832. [CrossRef]

70. Mitchell, R.H. Kimberlites: Mineralogy, Geochemistry and Petrology; Plenum Press: New York, NY, USA, 1986 ; p. 406.

71. Davies, G.R.; Spriggs, A.J.; Nixon, P.H. A Non-cognate Origin for the Gibeon Kimberlite Megacryst Suite, Namibia: Implications for the Origin of Namibian Kimberlites. J. Petrol. 2001, 42, 159-172. [CrossRef]

72. Boyd, F.R.; Nixon, P.H. Origin of the ilmenite-silicate nodules in kimberlites from Lesotho and South Africa. In Lesotho Kimberlites; Nixon, P.H., Ed.; Lesotho National Development Corporation: Maseru, Lesotho, 1973; pp. 254-268.

73. Schulze, D.J. Cr-Poor Megacrysts from the Hamilton Branch Kimberlite, Elliott County, Kentucky. Dev. Petrol. 1984, 11, 97-108. [CrossRef]

74. Nowell, G.M.; Pearson, D.G.; Bell, D.R.; Carlson, R.W.; Smith, C.B.; Kempton, P.D.; Noble, S.R. Hf Isotope Systematics of Kimberlites and their Megacrysts: New Constraints on their Source Regions. J. Petrol. 2004, 45, 1583-1612. [CrossRef]

75. Altunkaynak, Ş.; Ünal, A.; Howarth, G.H.; Aldanmaz, E.; Nývlt, D. The origin of low-Ca olivine from ultramafic xenoliths and host basaltic lavas in a back-arc setting, James Ross Island, Antarctic Peninsula. Lithos 2019, 342-343, 276-287. [CrossRef] 
76. Foley, S.F.; Musselwhite, D.S.; van der Laan, S.R. Melt compositions from ultramafic vein assemblages in the lithospheric mantle: A comparison of cratonic and non-cratonic settings. In Proceedings of the 7th International Kimberlite Conference, Cape Town, South Africa, 11-17 April 1998; pp. 238-246.

77. Ammannati, E.; Jacob, D.E.; Avanzinelli, R.; Foley, S.F.; Conticelli, S. Low Ni olivine in silica-undersaturated ultrapotassic igneous rocks as evidence for carbonate metasomatism in the mantle. Earth Planet. Sci. Lett. 2016, 444, 64-74. [CrossRef]

78. Howarth, G.H.; Harris, C. Discriminating between pyroxenite and peridotite sources for continental flood basalts (CFB) in southern Africa using olivine chemistry. Earth Planet. Sci. Lett. 2017, 475, 143-151. [CrossRef]

79. Yang, Z.-F.; Li, J.; Liang, W.-F.; Luo, Z.-H. On the chemical markers of pyroxenite contributions in continental basalts in Eastern China: Implications for source lithology and the origin of basalts. Earth Sci. Rev. 2016, 157, 18-31. [CrossRef]

80. Tompkins, L.A.; Haggerty, S.E. Groundmass oxide minerals in the Koidu kimberlite dikes, Sierra Leone, West Africa. Contrib. Miner. Petrol. 1985, 91, 245-263. [CrossRef]

81. Robles-Cruz, S.E.; Watangua, M.; Isidoro, L.; Melgarejo, J.C.; Galí, S.; Olimpio, A. Contrasting compositions and textures of ilmenite in the Catoca kimberlite, Angola, and implications in exploration for diamond. Lithos 2009, 112, 966-975. [CrossRef]

82. Castillo-Oliver, M.; Melgarejo, J.C.; Galí, S.; Pervov, V.; Gonçalves, A.O.; Griffin, W.L.; Pearson, N.J.; O’Reilly, S.Y. Use and misuse of Mg- and Mn-rich ilmenite in diamond exploration: A petrographic and trace element approach. Lithos 2017, 292-293, 348-363. [CrossRef]

83. Haggerty, S.E.; Hardie, R.B.; McMahon, B.M. The mineral chemistry of ilmenite nodule associations from the Monastery diatreme. In The Mantle Sample: Inclusion in Kimberlites and Other Volcanics; American Geophysical Union (AGU): Washington, DC, USA, 1979; pp. 249-256.

84. Mitchell, R.H. Petrology of hypabyssal kimberlites: Relevance to primary magma compositions. J. Volcanol. Geotherm. Res. 2008, 174, 1-8. [CrossRef]

85. Russell, J.K.; Porritt, L.A.; Lavallée, Y.; Dingwell, D.B. Kimberlite ascent by assimilation-fuelled buoyancy. Nat. Cell Biol. 2012, 481, 352-356. [CrossRef] [PubMed]

86. Dasgupta, R.; Hirschmann, M.M.; Smith, N.D. Partial Melting Experiments of Peridotite $+\mathrm{CO}_{2}$ at 3 GPa and Genesis of Alkalic Ocean Island Basalts. J. Petrol. 2007, 48, 2093-2124. [CrossRef]

87. Moore, A.E. Olivine: A monitor of magma evolutionary paths in kimberlites and olivine melilitites. Contrib. Miner. Petrol. 1988, 99, 238-248. [CrossRef]

88. Fitzpayne, A.; Giuliani, A.; Maas, R.; Hergt, J.; Janney, P.; Phillips, D. Progressive metasomatism of the mantle by kimberlite melts: $\mathrm{Sr}-\mathrm{Nd}-\mathrm{Hf}-\mathrm{Pb}$ isotope compositions of MARID and PIC minerals. Earth Planet. Sci. Lett. 2019, 509, 15-26. [CrossRef]

89. Ionov, D.A.; Chanefo, I.; Bodinier, J.-L. Origin of Fe-rich lherzolites and wehrlites from Tok, SE Siberia by reactive melt percolation in refractory mantle peridotites. Contrib. Miner. Petrol. 2005, 150, 335-353. [CrossRef]

90. Kopylova, M.; Nowell, G.; Pearson, D.; Markovic, G. Crystallization of megacrysts from protokimberlitic fluids: Geochemical evidence from high-Cr megacrysts in the Jericho kimberlite. Lithos 2009, 112, 284-295. [CrossRef]

91. Moore, A.; Belousova, E. Crystallization of Cr-poor and Cr-rich megacryst suites from the host kimberlite magma: Implications for mantle structure and the generation of kimberlite magmas. Contrib. Miner. Petrol. 2005, 149, 462-481. [CrossRef] 